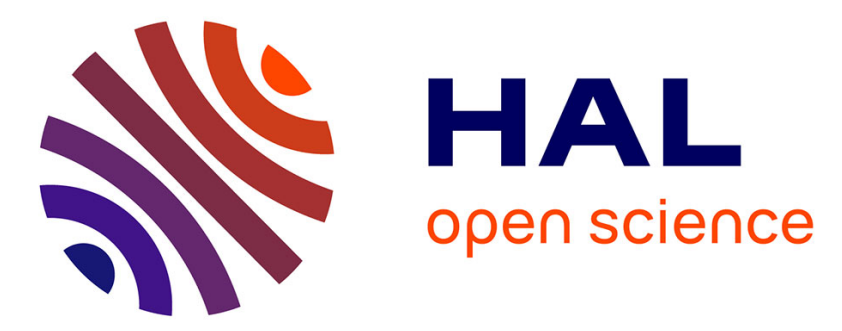

\title{
Ceramics with metallic lustre decoration. A detailed study of Islamic productions from the 9th century until the Renaissance
}

Delhia Chabanne, Marc Aucouturier, Anne Bouquillon, Evelyne

Darque-Ceretti, Sophie Makariou, Xavier Dectot, Antoinette Faÿ-Hallé, Delphine Miroudot

\section{To cite this version:}

Delhia Chabanne, Marc Aucouturier, Anne Bouquillon, Evelyne Darque-Ceretti, Sophie Makariou, et al.. Ceramics with metallic lustre decoration. A detailed study of Islamic productions from the 9th century until the Renaissance. Matériaux \& Techniques, 2012, 100 (1), pp.47-68. 10.1051/mattech/2011142 . hal-00686405

\section{HAL Id: hal-00686405}

https://hal-mines-paristech.archives-ouvertes.fr/hal-00686405

Submitted on 11 Apr 2012

HAL is a multi-disciplinary open access archive for the deposit and dissemination of scientific research documents, whether they are published or not. The documents may come from teaching and research institutions in France or abroad, or from public or private research centers.
L'archive ouverte pluridisciplinaire HAL, est destinée au dépôt et à la diffusion de documents scientifiques de niveau recherche, publiés ou non, émanant des établissements d'enseignement et de recherche français ou étrangers, des laboratoires publics ou privés. 


\title{
Surfaces: traitement, revêtements, décontamination, pollution, etc. / Surfaces: processings, coating, decontamination, pollution, etc.
}

\section{Ceramics with metallic lustre decoration. A detailed study of Islamic productions from the 9th century until the Renaissance ${ }^{\star}$}

\author{
D. Chabanne1, M. Aucouturier', A. Bouquillon', E. Darque-Ceretti², \\ S. Makariou ${ }^{3}$, X. Dectot ${ }^{4}$, A. Faÿ-Hallé ${ }^{5}$ and D. Miroudot ${ }^{3}$ \\ 1 C2RMF (UMR CNRS 171), Palais du Louvre, 14 quai François Mitterrand, 75001 Paris, France \\ e-mail: [marc.aucouturier; anne.bouquillon]@culture.gouv.fr; delhia.chabanne@gmail.com \\ 2 MINES-ParisTech, CEMEF (UMR CNRS 7635), BP 207, 06904 Sophia-Antipolis Cedex, France \\ e-mail: evelyne.darque-ceretti@mines-paristech.fr \\ 3 Musée du Louvre, DAl, 75001 Paris, France \\ e-mail: [sophie.makariou; delphine.miroudot]@louvre.fr \\ 4 Musée national du Moyen-Âge, 6 pl. Paul Painlevé, 75005 Paris, France \\ e-mail: xavier.dectot@culture.gouv.fr \\ 5 Previously at Musée national de la Céramique, 92310 Sèvres, France \\ e-mail: antoinette.halle@wanadoo.fr
}

Key words:

Ceramic; metallic lustre; ion beam analyses; Islam

Mots-clés :

Céramique ; lustre métallique ; analyses par faisceaux d'ions; Islam

Received 12 January 2011 accepted 21 December 2011

\begin{abstract}
This paper describes research on the technological evolution of glazed ceramics with a metallic lustre decoration starting from their emergence in the Near East until the Hispano-Moresque productions. That research covers the main known Islamic production sites and periods: Abbasid (Mesopotamia); Fatimid (Egypt); Timurid, Mongol, and Safavid (Iran); Ayyubid and Mamluk (Syria); Nasrid and Hispano-Moresque (Spain). It was allowed by the access to more than hundred full preserved objects or fragments supplied by French national museums (musée du Louvre DAl, musée national du Moyen-Âge, musée national de Céramique). The characterisation of the composition and structure of the ceramics and of their decoration is mostly done through non-destructive analyses methods. The thickness and metal content of the surface lustre layers are quantified thanks to ion beam analyses performed on a particle accelerator: PIXE (particle-induced X-ray emission) for the terracotta and glazes composition and RBS (Rutherford backscattering spectrometry) for the thickness and metal content of the lustre surface layers. The preliminary results show that the features of the decorated ceramics have undergone dramatic variations when transmitted from a production to another, not only, as expected, in the composition of terracotta and glazes, but also in the thickness, the structure and the composition distribution of the lustre layers.
\end{abstract}

Résumé - Céramiques à décor de lustre métallique. Connaissance détaillée des productions de I'Islam entre le 9ème siècle et la Renaissance. Cet article décrit une campagne de travaux sur l'évolution technique des décorations de lustre métallique sur des céramiques glaçurées, depuis l'émergence de cette technique au Proche-Orient jusqu'aux productions hispano-mauresques. Ce travail concerne les principaux sites et périodes de production islamiques : abbasside (Mésopotamie); fatimide (Égypte); timouride, mongole et safavide (Iran); ayyubide et mamelouk (Syrie); nasride et hispano-mauresque (Espagne).

$\star$ This article gathers the results of experimental measurements completed during the years 2005-2006 and interpreted during the years 2007-2008. Because of various edition problems, they could not be published earlier than now.

The published online version of this article is a fully coloured version. 


\begin{abstract}
Il a pu se dérouler grâce à l'accès à plus d'une centaine d'objets parfaitement préservés conservés par plusieurs musées nationaux français (musée du Louvre DAl, musée national du Moyen-Âge, musée national de la Céramique). La caractérisation de la composition et de la microstructure des céramiques et de leurs décors est principalement effectuée par des méthodes d'analyse non destructives. L'épaisseur et la concentration en métaux des couches superficielles de lustre sont quantifiées par utilisation d'analyses par faisceaux d'ions chargés sur un accélérateur de particules : PIXE (émission X induite par particules) pour la composition des terres cuites et des glaçures; RBS (retrodiffusion élastique de particules Rutherford) pour l'épaisseur et la concentration en métaux des couches superficielles de lustres. Les résultats montrent que les caractéristiques des céramiques décorées ont subi des variations considérables au cours de la transmission du savoir-faire d'une production à l'autre, non seulement, comme attendu, pour ce qui concerne la composition des terres cuites et des glaçures, mais aussi pour ce qui concerne l'épaisseur, la microstructure et la distribution en profondeur des compositions des couches de lustres.
\end{abstract}

\section{II} $\mathrm{t}$ is a common statement that productions of ceramic art and craft industry are regarded as testimonies of a past civilisation. Indeed, starting from a material as ordinary and "primary" as earth, any enrichment and creation, any utilisation testifies to the technological progress and the material and spiritual needs of a period, a period which can be identified because clay keeps the memory of places and times.

In the 9th century, during the most brilliant period of Islamic civilisation in Mesopotamia, under the Abbasid caliphate, appeared an outstanding technique of ceramic decoration: lustre, a precursory nanotechnology, a true alchemy which is able to transform simple earth into infinitely precious objects, giving them magnificent shine, including the appearance of gold [1-3]. That kind of decoration is related to a very sophisticated process which creates on the surface of a glazed ceramic a layer of vitreous matter with sub-micron thickness containing metallic particles (copper and silver) with a nanometric diameter [3]. It confers upon the surface a particular coloured aspect, often metallic in specular reflection. The fabrication and use of lustred ceramics were propagated across the Islamic world as far as Spain, leading to the creation of the Italian majolica in the Renaissance period [1,4].

Much research has been dedicated during the last few decades to the circumstances of propagation of that technique over centuries [1], to the iconographical, typological and analytical description of the various productions observed in the Islamic world [2,5] and to the classification and reproduction attempts of the different fabrication recipes listed in known documents of the Moslem tradition or in pottery treatises $[1-3,6]$. Other work has been devoted to the characterisation of a limited number of objects from excavations or kept in collections [5,7], and to the interpretation of the very particular optical properties which bring them their peculiar aspect [8-10].

Our aim is not to add supplementary data to the now well-established knowledge (see $[4,5,7]$ and references included therein) concerning the fabrication process principles or the general structure of the surface layers of ceramics with a metallic lustre decoration. It is more to attempt a study, based on structural criteria that are as precise as possible, of the ways that particular knowhow conquered first the Islamic world and later southern Europe, starting from the initial radiating source, and which transformations this know-how may have undergone in its route. This could be done thanks to the kind opening up of their collections by the curators and staff of several national French museums: the Islamic Art Department (DAI) of the Louvre museum; the Musée national du Moyen-Age; and the Musée national de Céramique de Sèvres. The period and geographical range concerned start from the 9th century Mesopotamian production and end with the Hispano-Moresque objects fabricated in the Spanish east coast workshops during the 14th to 17th centuries (plus some plates produced near Valencia in Spain during the 18th century), including the production of a number of Islamic centres in Egypt, Syria, Iran, North Africa and Spain. More than 110 objects (entire pieces or shards) from those museum collections were 
characterised. This work does not take into account study of the optical properties of the lustre layers and their modelling, which were conducted by researchers of a collaborating laboratory, the "Institut des NanoSciences de Paris", with their own expertise $[8,9]$.

The present article shows that it is possible to establish criteria for differentiating the productions, thanks to the use, in addition to characterisation methods commonly used in the numerous published works, such as scanning electron microscopy, X-ray diffraction, etc. (see $[4,5,7]$ and references included therein), of original, powerful, nondestructive methods for the determination of the structure and composition of surface layers.

\section{Presentation and short history of the lustred ceramic. Studied corpus}

The process steps to obtain a glazed ceramic with lustre decoration are as follows [1-3]: after the usual two firing sequences (hightemperature firing of the ceramic body, then application and firing at intermediate temperature of the vitreous glaze, coloured or not), an additional treatment of annealing at moderate temperature (ca. $500-600{ }^{\circ} \mathrm{C}$ ) is performed in the presence of a clayey mixture containing, among others, metallic salts and organic compounds (Fig. 1). This latter treatment is operated in a partially reducing atmosphere and leads to the formation of metal nanoparticles which remain embedded in a thin surface layer of vitreous glaze.

The technique appears to have been initiated for glazed ceramics in the 9th century in the Mesopotamian area [2] under the Abbasid dynasty (750-1055), probably in Samara, Susa, Baghdad and Basra. This type of ceramic was fabricated and used under the great Islamic dynasties [2]. First, in Egypt, more precisely in Fustat, where a significant production appeared under the Fatimids (969-1171), with perhaps some preceding examples in that region (so-called pre-Fatimids). Then the technique diffused all over the Orient: in Syria (mainly Raqqa) under the Ayyubids (1171-1250) and during the Mamluk period (1250-1517); in Iran (notably in Kashan or Rayy), first under the Seldjukids (1038-1194) and Ilkhanids (1256-1353), then under the Timurids (13701506) and Safavids (1501-1732) with some examples (a renewal?) under the Gadjars (1779-1924). Simultaneously, the technique appears in the Occident, in southern Spain as soon as the taifa merged after the dissolution of the Spanish Umayyad caliphate and long after, under the Nasrid dynasty (12371492); its apogee, in the 14th-15th centuries, gave rise to the Hispano-Moresque ceramic that was elaborated over five centuries in the Valencia region until the 18th century. The technique found a new application in Renaissance Italy (15th and 16th centuries) where Deruta and Gubbio become the most famous production centres of lustred glazed majolica [4].

The first Abbasid examples show a real mastering of the technique with, in particular, the fabrication of polychrome decorations (Figs. 2A and 2B). Later, polychromy was progressively lost (Fig. 2D) but coloured glazes (blue, green, aubergine, etc.) or overapplied colour may be associated with the lustre (Figs. 2C and 2E). The latest examples (18th century), in Safavid Iran or in eastern Spain exhibit decoration with a coppered aspect (Fig. 2F).

A collaboration was established with three French national museums (Louvre museum, Musée national du Moyen-Âge and Musée national de Céramique de Sèvres) and a private collector. They provided the objects analysed (plates, vases, fragments, etc.) issued from the previously cited productions (Tab. 1 and Appendix 1). Particular care was given to the choice of the specimens as their decoration should be characteristic of a production (neither coming from isolated attempts nor from failures; this is especially true for shards). Moreover, the choices contain the available different technological options of a given period (nature of the terracotta and of the glaze). To that list were added (also included in Tab. 1) a set of objects studied in the framework of a collaboration with a researcher at Seville university [11] sponsored by the European programme EuARTECH, and, for comparison, 2 pieces produced by a modern Spanish artisan [12].

Altogether, 124 objects were analysed during that programme (Fig. 3). The results 


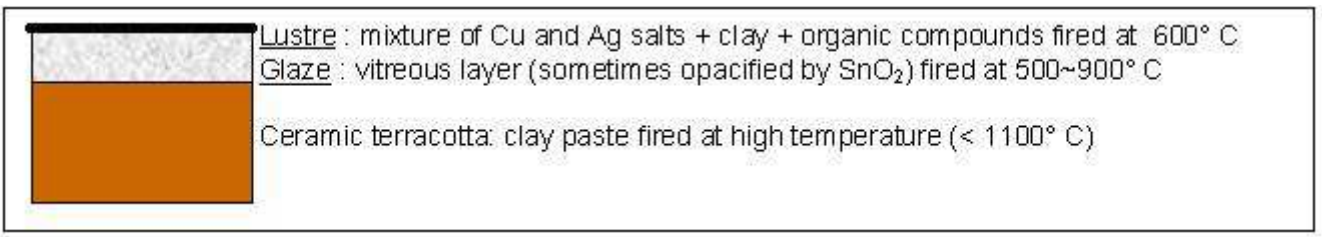

Fig. 1. Fabrication principle and structure of a glazed ceramic with lustre decoration.

Fig. 1. Principe de fabrication et microstructure d'une céramique glaçurée à décor de lustre métallique.
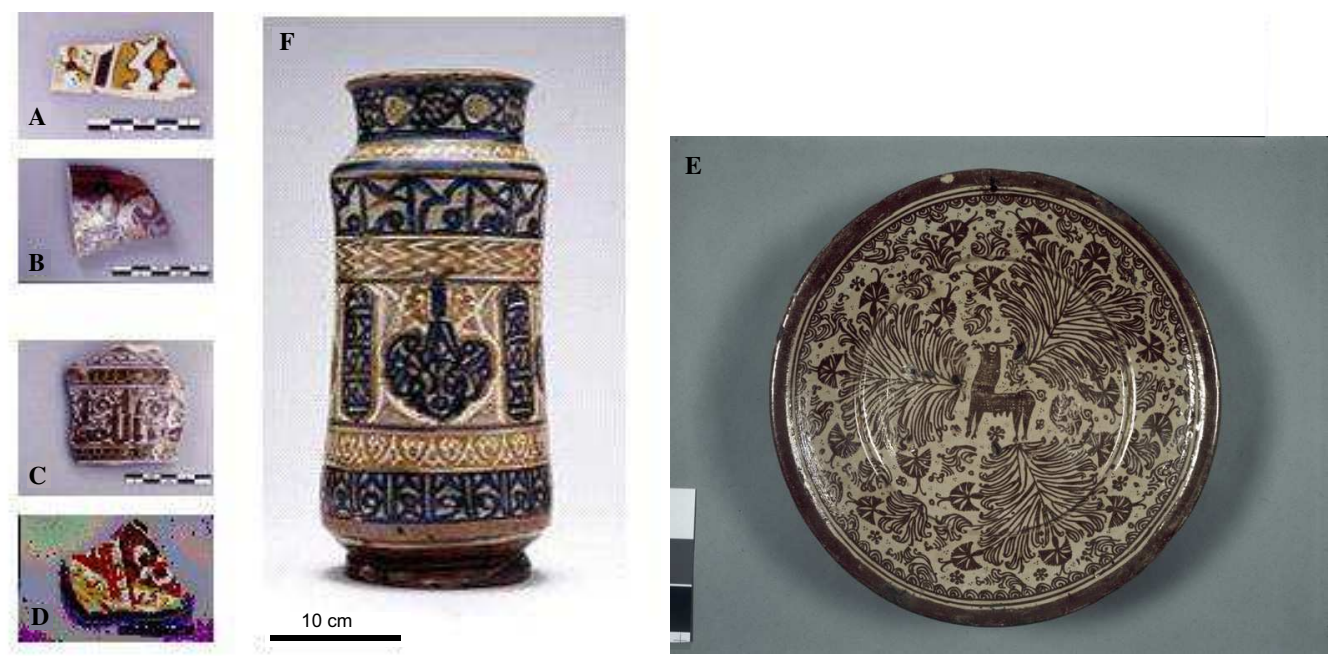

Fig. 2. Examples of the studied objects (whole pieces or fragments): Abbasid period (A \& B, (C) C2RMF, D. Bagault), Fatimid period (C \& D, (C) C2RMF, D. Bagault) and Hispano-Moresque period (E \& F, Musée du Moyen-Âge, Cluny, (C) C2RMF, D. Bagault).

Fig. 2. Exemples d'objets étudiés (pieces entières ou tessons) : période abbasside ( $A$ et B, CC2RMF, D. Bagault), période fatimide (C et D, (C) $2 R M F, D$. Bagault) et période hispano-moresque (E et F, Musée du Moyen-Âge, Cluny, (C) C2RMF, D. Bagault).

may also be compared with results obtained on Italian majolica in the framework of a former study [4] done in the present laboratory in collaboration with the Italian CNR, the Gubbio museum (Italy), the Art Objects department of the Louvre museum, the Musée national de la Renaissance (Ecouen, France) and the Musée national de Céramique de Sèvres.

\section{Experimental approach and procedure}

A detailed knowledge of the surface layers responsible for the lustre aspect needs a multiple method approach that is as minimally invasive as possible for these cultural heritage artefacts [13].

Observation on different scales by optical microscopy, conventional and highresolution scanning electron microscopy
(SEM and HR-SEM), atomic force microscopy (AFM) and transmission electron microscopy (TEM) on cross-sections reveals their fine microstructure (Fig. 4) [14,15].

Tiny metal particles are visible, with an average diameter of 10 to a few tens of nanometres, sometimes agglomerated as clusters with a larger size. In the present case, the HR-SEM observation shows that the particles are in fact lying under a surface film with a vitreous-like aspect that is sometimes broken, confirming observations reported in the literature $[3,7,14]$.

The size and the nature of the particles may be measured by grazing incidence $X$-ray diffraction. In the diagrams of Figure 5 a broadening of the metallic silver diffraction peaks is observed. Through the application of the Sherrer formula [16], a measurement of that broadening, corrected by the instrumental broadening obtained 


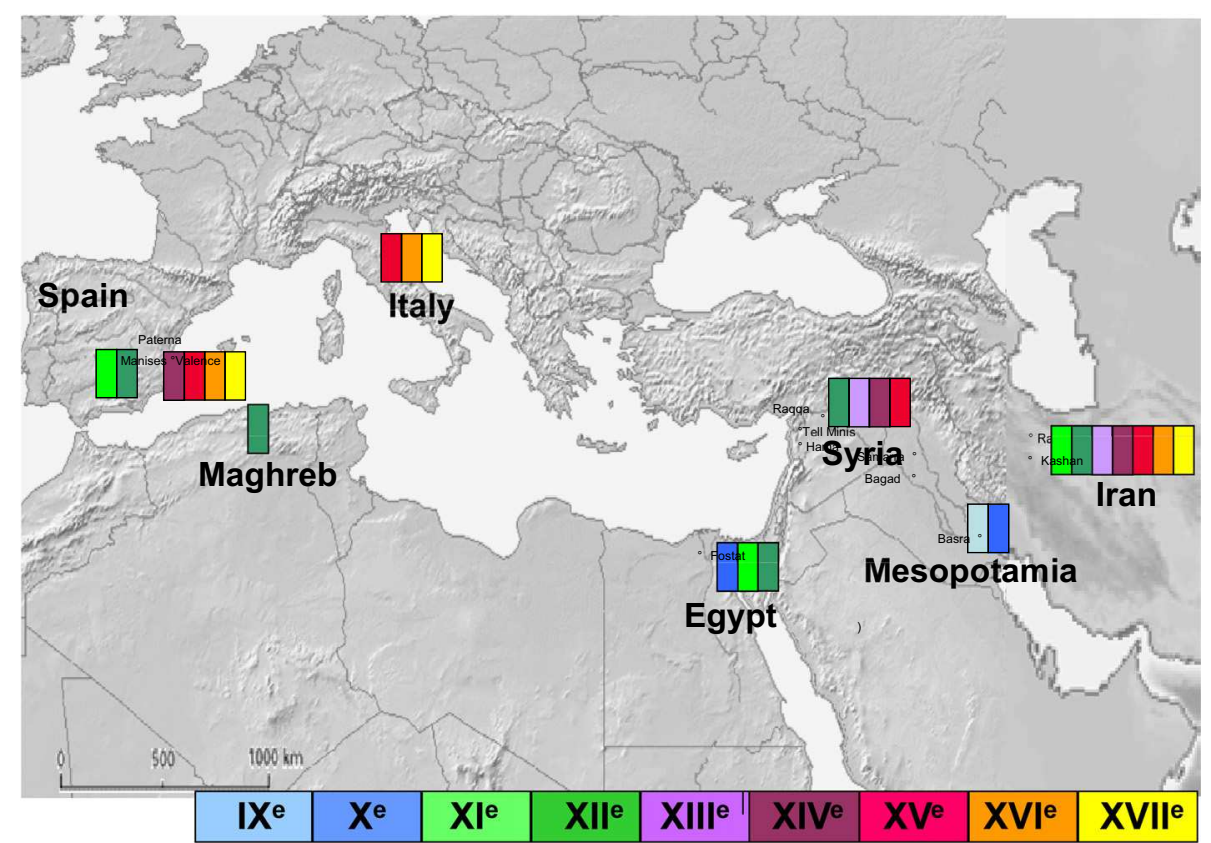

Fig. 3. Origin and dating of the studied objects.

Fig. 3. Origine et dates des objets étudiés.

Table 1. Summing up of the glazed ceramics with lustre decoration studied in 2005-2006 (entire objects or fragments). Tableau 1. Résumé des céramiques émaillées à décor de lustre étudiées en 2005-2006 (objets entiers ou fragments).

\begin{tabular}{|c|c|c|c|}
\hline Period & Production site & Number of specimens & Conservation place \\
\hline Abbasid 9th-10th cent. & Susa, Mesopotamia & 23 & DAI, Louvre museum \\
\hline 9th-11th cent.* Abbasid? & Mesopotamia? (found in Fustat) & $8^{*}, * * *$ & Private collection \\
\hline Pre-Fatimid ${ }^{*}$ & Fustat, Egypt & $4^{*}$ & DAI, Louvre museum \\
\hline Fatimid (989-1171) & Fustat, Egypt & $\begin{array}{l}6\left(+4^{*}\right) \\
5\left(+1^{*}\right)\end{array}$ & $\begin{array}{c}\text { Musée national de Céramique, Sèvres } \\
\text { DAI, Louvre museum }\end{array}$ \\
\hline Ayyubid (1171-1250) & Syria & $7\left(+1^{*}\right)$ & DAI, Louvre museum \\
\hline Tell Minis 12th cent. & Syria & 1 & DAI, Louvre museum \\
\hline Pre-Mongol (1038-1194) & Iran & 12 & DAI, Louvre museum \\
\hline Mongol (1256-1353) & Iran & 10 & DAI, Louvre museum \\
\hline Timurid (1370-1506) & Iran & 4 & DAI, Louvre museum \\
\hline Safavid (1501-1732) & Iran & 6 & DAI, Louvre museum \\
\hline Mamluk (1250-1510) & Syria & 2 & DAI, Louvre museum \\
\hline End of 11th cent. & La Qala de Banu Hammad, Algeria & 3 & DAI, Louvre, UCAD deposit \\
\hline \multirow{2}{*}{$\begin{array}{l}\text { Islamic Spain, } \\
\text { 12th-14th centuries }\end{array}$} & Andalusia, Spain & $3^{*}$ & DAI, Louvre museum \\
\hline & & 10 & Musée du Moyen-Âge, Cluny \\
\hline & Valencia and Seville, Spain & & \\
\hline \multirow[t]{2}{*}{ 15th-18th centuries } & & 3 & Musée National de Céramique, Sèvres \\
\hline & & $7^{* *}$ & Triana workshop, Seville \\
\hline Modern & Granada, Spain & 2 & \\
\hline
\end{tabular}

\footnotetext{
* uncertain attribution.

** kindly supplied by A. Polvorinos del Rio, Seville university [11].

*** kindly supplied by A. Kaczmarczyk [15].
} 


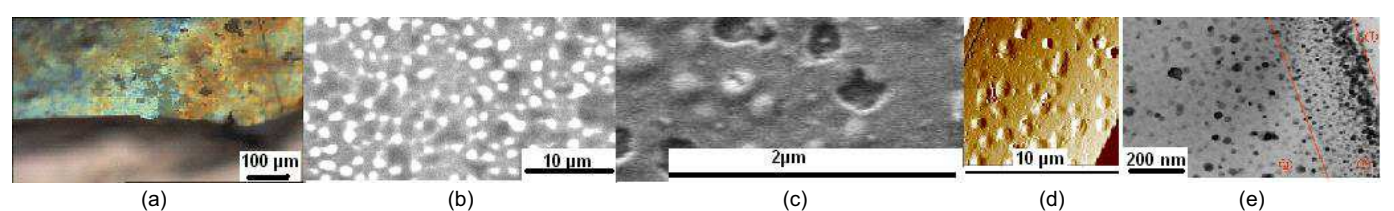

Fig. 4. Observation of a lustred ceramic on different scales: (a) optical microscope; (b) conventional SEM; (c) HR-SEM; (d) AFM (tapping mode, z scale not specified); (e) TEM.

Fig. 4. Observation d'une céramique lustrée à différentes échelles : (a) microscope optique; (b) microscope électronique à balayage (MEB) conventionnel; (c) MEB à haute résolution; (d) microscope à force atomique ; (e) microscope électronique en transmission (MET).

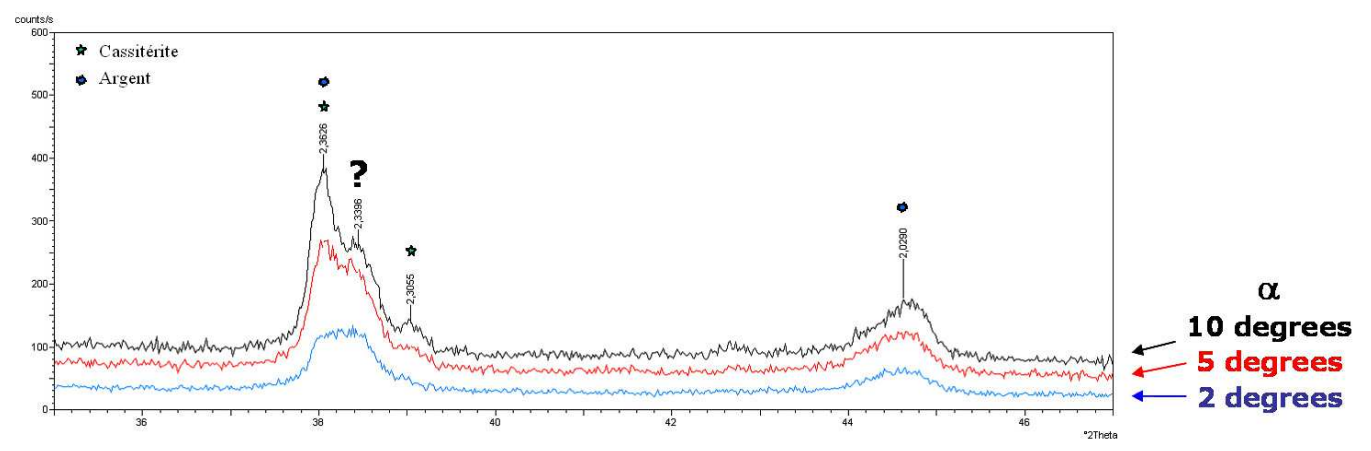

Fig. 5. Grazing X-ray diffraction on a modern lustre surface ( $\alpha=$ incidence angle).

Fig. 5. Diffraction de rayons $X$ rasants sur la surface d'un lustre moderne ( $\alpha=$ angle d'incidence).

on a standard recrystallised silver specimen, leads to the calculation of the size of the smallest silver particles. In the example shown, the estimated size is $12 \mathrm{~nm}$. As seen in Figure 5 and checked through calculation, the X-ray incidence angle has no influence on the peak broadening and particle size evaluation. That evaluation could not be made by small-angle X-ray scattering (SAXS) because the roughness of the specimens is too high.

The non-identified peak appearing for the $d=0.234 \mathrm{~nm}$ interreticular distance is discussed in [15]; it may be due to a strain effect.

The aim of the present study was to investigate the eventual technological evolution of the lustre fabrication, through a comparison of the composition and structure of the ceramics and lustre layers from the different production centres.

Three main criteria were used for that comparison:

- the nature and structure of the ceramic bodies;

- the composition and microstructure of the glazes;
- the thickness and composition of the different surface layers which constitute the actual lustre.

In order to quantify these criteria, several laboratory methods were used, with a preference given to non-destructive analysis methods. Practically all objects were analysed through ion beam analysis techniques on the $4 \mathrm{MV}$ peletron particle accelerator AGLAE (NEC Inc.) with an extracted beam available in C2RMF (Centre de Recherche et de Restauration des Musées de France) [17]: PIXE spectrometry under a $3 \mathrm{MeV}$ energy proton beam associated with the quantification code GUPIX [18] for characterisation of the elemental chemical composition (major, minor and trace elements); and RBS under a $3 \mathrm{MeV}$ alpha particle beam, which allows the quantitative determination of the in-depth composition profiles over a few micrometres from the surface; the particle beam (diameter lower than $50 \mu \mathrm{m}$ ) is extracted to free atmosphere in a helium flux by crossing a $\mathrm{Si}_{3} \mathrm{~N}_{4}$ window of $100 \mathrm{~nm}$ thickness. PIXE has a high sensitivity and the limit of detection for heavy elements such as lead, copper and silver is of the order of a few tens of ppm. RBS is also very sensitive to heavy elements, with 

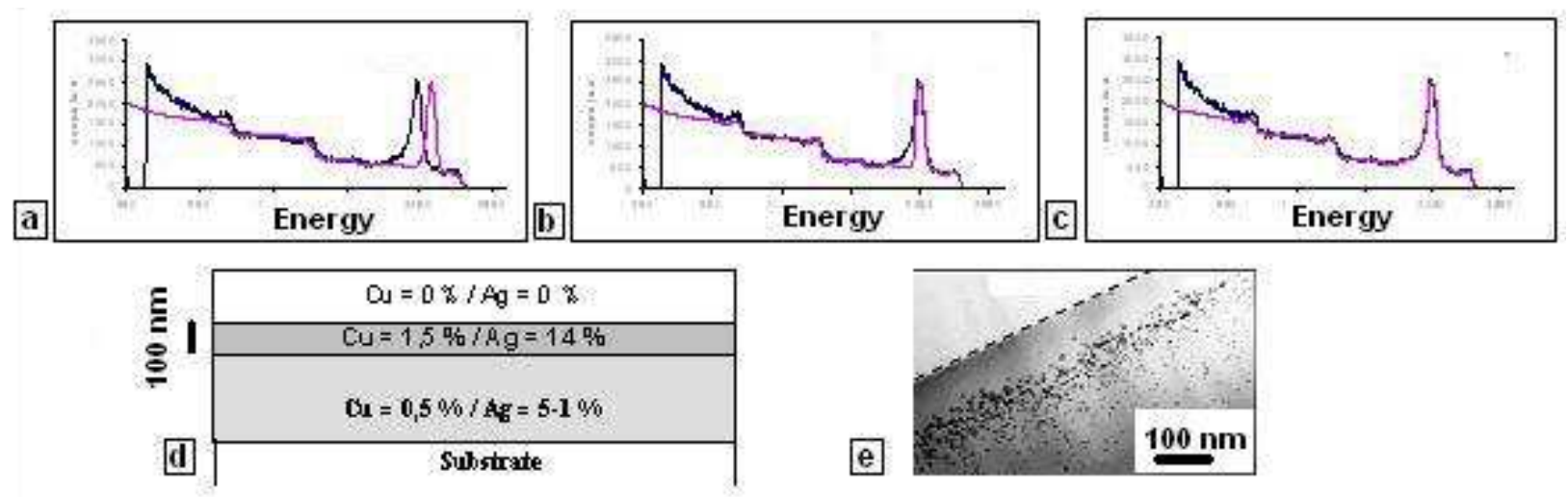

Fig. 6. Experimental (curves with noise) and simulated RBS spectra on a specimen of lustred ceramic; (a) simulation of the glaze covered with a layer containing $\mathrm{Cu}$ and $\mathrm{Ag}$; (b) addition of a layer containing neither copper nor silver; (c) insertion of an intermediary layer with a $\mathrm{Cu}$ and/or Ag gradient; (d) simplified result of the simulation; (e) TEM image of a cross-section of a similar specimen (CCEMES-CRPAA, P. Sciau).

Fig. 6. Spectres RBS expérimentaux (courbes bruitées) et simulés sur un échantillon de céramique lustrée; (a) simulation de la glaçure couverte d'une couche contenant $\mathrm{Cu}$ et $\mathrm{Ag}$; (b) addition d'une couche sans $\mathrm{Cu} n \mathrm{nig}$; (c) insertion d'une couche intermédiaire avec un gradient de Cu et/ou Ag; (d) résultat simplifié de la simulation; (e) image MET d'une section transverse d'un échantillon similaire (C) CEMES-CRPAA, P. Sciau).

a precision better than 10 relative percent. Its precision is much worse (several 10\%) for light elements such as silicon, sodium, oxygen, etc.

The RBS spectra are interpreted by using the SIMNRA calculation code [19]: a virtual specimen is built, constituting a discrete number of superposed layers whose compositions and thicknesses are adjusted until the simulated spectrum fits the experimental spectrum. Figure 6 shows an example of the process followed during the simulation and comparison of the result with observation in the transmission electron microscope of the cross-section obtained on a similar archaeological specimen [20]: the spectrum of the bare glaze, considered as homogeneous in depth, is simulated thanks to the knowledge of its composition through PIXE analysis; then a glaze layer containing adequate contents of copper and/or silver is added to the top surface of the virtual specimen to try to simulate the experimental spectrum (Fig. 6a); one observes that the energies of the peaks corresponding to both $\mathrm{Cu}$ and Ag may not fit with those observed; it is then necessary to add to the virtual specimen a layer containing neither of the metals, whose thickness is adjusted to provoke the adequate energy shift (Fig. 6b); to achieve the simulation, one has to insert over or under the principal metal-containing layer one or several intermediate layers with decreasing $\mathrm{Cu}$ and/or Ag contents in order to simulate concentration gradients before reaching the glaze (Fig. 6c). The result appears in the scheme of Figure $6 \mathrm{~d}$. Comparison with the TEM observation (Fig. 6e) shows that the RBS simulation result is in agreement with the actual structure, and this validates the methodological process. The precision obtained on the thickness of the layers containing metallic ( $\mathrm{Cu}$ and/or $\mathrm{Ag}$ ) elements is estimated to be around 10 to $20 \mathrm{~nm}$ in the present conditions.

It must be kept in mind that the representation of the subsurface distribution as a succession of discrete layers, a consequence of the simulation procedure of the SIMNRA code, is schematic. In fact, as shown in the TEM images of Figures 4 and 6, the distribution of the metallic nanoparticles as well as the concentrations of other elements vary continuously as a function of the depth.

In complement, observations and quantitative microanalyses were carried out by optical microscopy and microanalytical scanning electron microscopy (SEM-EDS, Philips controlled vacuum scanning electron microscope) on microsamples when sampling was possible (stratigraphic cross-sections embedded in resin and polished down to $1 / 4 \mu \mathrm{m}$ diamond paste), in order to specify the nature, the composition and the microstructure 
Table 2. Average composition of the terracotta in wt \%, measured by PIXE. Siliceous pastes are on a grey background. S.D. = standard deviation.

Tableau 2. Composition moyenne de la terre cuite en \% du poids, mesurée par PIXE. Les pâtes siliceuses sont sur un fond gris. S.D. = Écart-type.

\begin{tabular}{|c|c|c|c|c|c|c|c|c|c|c|c|c|c|}
\hline Provenance & & $\mathrm{Na}_{2} \mathrm{O}$ & $\mathrm{MgO}$ & $\mathrm{Al}_{2} \mathrm{O}_{3}$ & $\mathrm{SiO}_{2}$ & $\mathrm{P}_{2} \mathrm{O}_{5}$ & $\mathrm{SO}_{3}$ & $\mathrm{Cl}$ & $\overline{\mathrm{K}_{2} \mathrm{O}}$ & $\mathrm{CaO}$ & $\mathrm{TiO}_{2}$ & $\mathrm{MnO}$ & $\overline{\mathrm{Fe}_{2} \mathrm{O}_{3}}$ \\
\hline \multirow{2}{*}{ Abbassid } & mean & 2.26 & 7.08 & 12.56 & 45.91 & 0.20 & 1.90 & 0.78 & 1.37 & 19.64 & 0.59 & 0.14 & 7.35 \\
\hline & S.D. & 1.70 & 0.73 & 0.91 & 2.83 & 0.08 & 2.80 & 1.59 & 0.38 & 1.24 & 0.21 & 0.02 & 0.51 \\
\hline \multirow[t]{2}{*}{ Pre-Fatimid } & mean & 2.16 & 3.50 & 11.62 & 42.95 & 0.47 & 3.78 & 2.02 & 1.38 & 22.57 & 1.06 & 0.10 & 7.83 \\
\hline & S.D. & 1.5 & 0.9 & 2.3 & 7.6 & 0.4 & 4.2 & 2.3 & 0.3 & 6.6 & 0.3 & 0.0 & 1.3 \\
\hline \multirow[t]{2}{*}{ Fatimid } & mean & 1.39 & 3.56 & 12.34 & 47.60 & 0.50 & 2.09 & 0.66 & 1.20 & 21.81 & 0.98 & 0.09 & 7.18 \\
\hline & S.D. & 0.34 & 0.27 & 0.76 & 3.68 & 0.20 & 1.47 & 0.55 & 0.26 & 3.13 & 0.22 & 0.01 & 0.75 \\
\hline \multirow[t]{2}{*}{ Fatimid } & mean & 4.81 & 1.18 & 7.79 & 75.50 & 0.25 & 1.50 & 0.93 & 1.08 & 3.66 & 0.42 & 0.04 & 1.60 \\
\hline & S.D. & 1.11 & 0.79 & 1.02 & 3.15 & 0.13 & 1.52 & 0.52 & 0.23 & 1.31 & 0.06 & 0.05 & 0.20 \\
\hline \multirow[t]{2}{*}{ Ayyubid } & mean & 3.59 & 2.61 & 3.32 & 78.48 & 0.51 & 1.86 & 0.44 & 1.59 & 5.54 & 0.21 & 0.03 & 1.55 \\
\hline & S.D. & 0.57 & 0.59 & 1.36 & 5.03 & 0.69 & 2.30 & 0.40 & 0.93 & 2.02 & 0.19 & 0.01 & 0.30 \\
\hline \multirow[t]{2}{*}{ Pre-Mongol } & mean & 2.83 & 1.06 & 8.13 & 77.48 & 0.25 & 2.43 & 0.25 & 1.84 & 2.86 & 1.04 & 0.02 & 1.40 \\
\hline & S.D. & 0.33 & 0.34 & 2.36 & 3.46 & 0.17 & 1.91 & 0.10 & 0.37 & 1.07 & 0.36 & 0.01 & 0.47 \\
\hline \multirow[t]{2}{*}{ Mongol } & mean & 2.97 & 1.58 & 7.72 & 77.91 & 0.36 & 1.27 & 0.19 & 1.59 & 3.82 & 0.89 & 0.03 & 1.36 \\
\hline & S.D. & 0.30 & 0.48 & 1.96 & 3.64 & 0.28 & 1.68 & 0.11 & 0.31 & 1.23 & 0.26 & 0.01 & 0.30 \\
\hline Timurid & S.D. & 0.02 & 0.05 & 0.86 & 0.10 & 0.17 & 0.34 & 0.22 & 0.03 & 0.26 & 0.06 & 0.00 & 0.41 \\
\hline \multirow[t]{2}{*}{ Algeria } & mean & 0.91 & 2.32 & 14.06 & 40.61 & 0.38 & 1.18 & 0.17 & 0.61 & 30.43 & 1.07 & 0.09 & 7.30 \\
\hline & S.D. & 0.11 & 0.40 & 2.95 & 3.62 & 0.41 & 0.41 & 0.08 & 0.16 & 7.33 & 0.36 & 0.02 & 0.74 \\
\hline \multirow[t]{2}{*}{ Hispano-Moresque } & mean & 0.80 & 3.05 & 14.16 & 44.49 & 0.15 & 3.23 & 0.24 & 2.79 & 23.49 & 0.77 & 0.10 & 5.93 \\
\hline & S.D. & 0.18 & 0.47 & 0.94 & 3.08 & 0.26 & 1.75 & 0.13 & 0.89 & 3.40 & 0.30 & 0.07 & 0.42 \\
\hline
\end{tabular}

of the terracotta and the glazes. X-ray diffraction (Brücker D8 diffractometer) provided the necessary structural information. Some objects (the modern ones in particular) were studied by high-resolution scanning electron microscopy (HR-SEM, with a field emission gun, Leo 1450VP-SEM240, École des Mines de Paris), by AFM and by grazing incidence $X$-ray diffraction, in order to specify the structure of the extreme surface.

\section{Results and discussion}

\subsection{The pastes (terracotta)}

Table 2 gathers the measured average compositions of the terracotta, obtained by PIXE analysis. The results do not concern all objects: it was not always possible to measure the terracotta composition, especially for entire museum objects where no sampling was possible, and where the ion beam could not reach the clean paste body.

Two kinds of substrates are evidenced: in majority marly clays, beige to orange, and on the other hand, highly siliceous pastes, white, close to archaeological faïence.

The oldest objects (Abbasid period) found in Susa and Samara are made from a homogeneous body, a marly $(20 \% \mathrm{CaO})$ ferrous $\left(7 \% \mathrm{Fe}_{2} \mathrm{O}_{3}\right)$ clay (Tab. 2). This kind of paste is typical of productions from this region, as similar chemical compositions have already been found in the 4th millenary BC for Susa I decorated potteries [21]. It is related to the local earth, common and approved. The paste is clear enough despite relatively high iron content, because that element is incorporated during firing in pyroxene-type phases, avoiding the red colouration due to "free" iron. On all studied Abbasid potteries, no noticeable variation is observed, except varying contents of chlorides and sulphides attributed to burying salts or restoration products. That kind of marly clay is also found for pre-Fatimid and part of the Fatimid (between the 9th and 12th-13th centuries) potteries, confirming previous studies [22]. It is present later in Iran of the Timurid era and is exclusively used for the Spanish productions.

On the other hand, the substrate is always siliceous in Syria during the Ayyubid and Mamluk dynasties and in Iran for the pre-Mongol and Mongol productions.

Both kinds of paste are used during the Fatimid period and in Iran up to the 14th century. The siliceous paste mainly constitutes 
quartz grains embedded in an often alkaline matrix phase, following a tradition of antique Egyptian productions. It is, however, somewhat different in its higher alumina content $(7 \%)$, a proof of introduction into the mixture of small quantities of clay added to the alkaline flux.

As for the Safavids from the 17th century onwards, not mentioned in Table 2, it seems that both materials coexisted but this last statement needs to be confirmed, because the number of results is not large enough to be considered as valid.

\subsection{The glazes (Tab. 3)}

Glazes are distributed into two classes: alkaline glazes, which are always transparent, and lead-bearing glazes, which are generally opaque. Among the latter one may distinguish between those containing a low amount of tin (less than $10 \mathrm{wt} \% \mathrm{SnO}_{2}$ ) and those heavily opacified (about $20 \mathrm{wt} \% \mathrm{SnO}_{2}$ ).

The transparent glazes are mostly alkaline. With a somewhat high potassium content $\left(\approx 4 \quad w t \% \quad \mathrm{~K}_{2} \mathrm{O}\right)$, and colourless or greyish, they are typical of the first Abbassid productions. Under the Ayyubids and Safavids, glazes contain more sodium $\left(\approx 4-5 \mathrm{wt} \% \mathrm{Na}_{2} \mathrm{O}\right)$ and are sometimes coloured in blue or light green by cobalt and/or copper oxides (not mentioned in Tab. 3). In the workshops of the Spanish Levant after the 17th century colourless glazes with lead but without tin are applied, leaving the orange colour of the terracotta visible.

The opaque glazes always contain lead, with $\mathrm{PbO}$ contents varying from $5 \mathrm{wt} \%$ under the late Abbasids to $40 \mathrm{wt} \%$ under the Fatimids and then in Spain. Opacification is obtained by a more or less high amount of tin, between 4 and $20 \mathrm{wt} \% \mathrm{SnO}_{2}$. The whitest pre-Fatimid and early Fatimid (9th10th centuries) ones contain the highest tin content.

Some background glazes are present as well as highlights coloured in violet, blue or green by, respectively, manganese (0.3 to $0.7 \mathrm{wt} \% \mathrm{MnO}$ ), cobalt (up to $0.3 \mathrm{wt} \% \mathrm{CoO}$ ) and copper (up to $1 \mathrm{wt} \% \mathrm{CuO}$ ).

The material choice for the terracotta and the glaze is a consequence of ceramic tra- ditions often thousands of years old, generally linked to the geological context, and sometimes also to aesthetic or technical constraints. One must keep in mind that alkaline glazes do not easily fit clayey pastes [23] For instance, in Syria, an always siliceous substrate is used between the paste and the alkaline glaze.

\subsection{The lustre composition and structure}

As stated in Section 2, the non-destructive analysis procedure followed in this study gives access to the distribution of elements in the first layers of the objects under the actual surface. The SIMNRA simulation used to interpret the RBS spectra (Fig. 6) describes these first layers in a simplified diagram of stacked discrete layers, although the reality is the existence of continuous variations of elements. Such a simplified description gives nevertheless a good evaluation of the most specific physico-chemical features of a given lustre. Figure 7 shows three examples obtained on specimens issued from different productions; the thicknesses of the different layers, and their copper and silver nanoparticle contents as quantified by the RBS spectra simulation are indeed in good agreement with cross-section TEM observations.

Following this evaluation mode, lustre can be schematically characterised by a succession of more or less thin layers, not always present in their totality:

- An extreme surface layer of glaze containing neither copper nor silver, not always present.

- A set of layers describing a concentration gradient of copper and/or silver.

- A "main layer" containing the maximum copper and/or silver amount.

- Again a set of layers with a concentration gradient of copper and/or silver, extending until the metal-free glaze substrate.

The presence or absence of these layers, their thicknesses, and their copper and silver contents were taken as criteria for the comparison of the various productions and the detection of possible evolutions between them. Another criterion was also considered: the volume fraction of copper and silver in each 
Table 3. Average composition of the glazes in wt \%, measured by PIXE. Discriminating elements for opaque lead glazes are in bold. Colouring additions (Co, Cu) are not mentioned.

Tableau 3. Composition moyenne des émaux en \% du poids, mesurée par PIXE. Les éléments discriminants pour glaçures au plomb opaques sont en gras. Les ajouts colorés (Co, Cu) ne sont pas mentionnés.

\begin{tabular}{|c|c|c|c|c|c|c|c|c|c|c|c|c|c|c|c|}
\hline Provenance & Type & $\mathrm{Na}_{2} \mathrm{O}$ & $\mathrm{MgO}$ & $\mathrm{Al}_{2} \mathrm{O}_{3}$ & $\mathrm{SiO}_{2}$ & $\mathrm{P}_{2} \mathrm{O}_{5}$ & $\mathrm{SO}_{3}$ & $\mathrm{Cl}$ & $\mathrm{K}_{2} \mathrm{O}$ & $\mathrm{CaO}$ & $\mathrm{TiO}_{2}$ & $\mathrm{MnO}$ & $\mathrm{Fe}_{2} \mathrm{O}_{3}$ & $\mathrm{SnO}_{2}$ & $\mathrm{PbO}$ \\
\hline Abbassid $1^{*}$ & transparent & 3.10 & 2.30 & 2.99 & 72.59 & 0.15 & 4.26 & 0.48 & 4.86 & 6.42 & 0.16 & 0.56 & 1.10 & 0.15 & 0.25 \\
\hline Abbassid $2^{*} \min$ & & 3.85 & 3.41 & 2.29 & 72.17 & 0.20 & 0.85 & 0.53 & 4.70 & 5.55 & 0.12 & 0.27 & 0.90 & 3.20 & 1.70 \\
\hline Abbassid $2^{*} \max$ & opaque & 0.63 & 1.67 & 2.82 & 51.55 & 1.02 & 8.48 & 0.65 & 2.28 & 6.21 & 0.06 & 0.12 & 0.72 & 12.78 & 8.00 \\
\hline Pre-Fatimid white & opaque & 1.41 & 0.08 & 2.29 & 43.81 & 0.00 & 0.00 & 0.21 & 3.12 & 0.65 & 0.26 & 0.01 & 0.51 & 18.46 & 29.00 \\
\hline Fatimid (2 spec.) & opaque & 1.70 & 0.10 & 1.90 & 48.45 & 0.02 & 0.00 & 0.14 & 3.27 & 0.85 & 0.33 & 0.01 & 0.54 & 7.85 & 34.60 \\
\hline Fatimid (2 spec.) & opaque & 0.86 & 0.09 & 1.56 & 38.54 & 0.00 & 0.00 & 0.29 & 1.55 & 0.57 & 0.34 & 0.01 & 0.44 & 14.54 & 40.75 \\
\hline Ayyubid & transparent & 8.54 & 2.54 & 1.89 & 74.68 & 0.43 & 1.06 & 0.44 & 2.61 & 5.88 & 0.15 & 0.08 & 1.40 & 0.00 & 0.01 \\
\hline Mamluk & transparent & 5.03 & 3.56 & 1.44 & 73.15 & 0.13 & 0.36 & 0.12 & 4.57 & 6.99 & 0.09 & 0.03 & 2.18 & 0.01 & 0.22 \\
\hline Pre-Mongol & opaque & 4.29 & 1.89 & 1.82 & 55.06 & 0.04 & 0.36 & 0.27 & 2.04 & 3.14 & 0.11 & 0.03 & 0.73 & 9.32 & 20.21 \\
\hline Mongol & opaque & 3.95 & 1.65 & 2.24 & 59.23 & 0.00 & 0.62 & 0.27 & 3.10 & 4.07 & 0.18 & 0.03 & 1.00 & 6.77 & 16.39 \\
\hline Timurid & opaque & 2.16 & 1.41 & 2.22 & 59.31 & nd & nd & 0.14 & 3.42 & 2.94 & 0.09 & 0.02 & 0.54 & 8.15 & 18.37 \\
\hline Safavid & transparent & 7.25 & 3.10 & 2.24 & 78.03 & 0.07 & 0.23 & 0.11 & 1.75 & 5.56 & 0.12 & 0.06 & 1.11 & 0.00 & 0.01 \\
\hline Pre-Nasrid and Nasrid & opaque & 1.20 & 0.49 & 0.93 & 45.15 & 0.06 & 0.00 & 0.05 & 2.32 & 1.42 & 0.07 & 0.01 & 0.40 & 6.70 & 40.96 \\
\hline Hispano-Moresque 1 (<17th cent.) & opaque & 0.73 & 0.30 & 1.85 & 46.37 & nd & 0.07 & 0.17 & 5.42 & 2.49 & 0.06 & 0.01 & 0.22 & 5.38 & 36.43 \\
\hline Hispano-Moresque 2 (18th cent.) & transparent & 0.57 & 0.11 & 1.31 & 55.73 & nd & 0.08 & 0.19 & 5.02 & 1.35 & 0.06 & 0.01 & 0.40 & 0.07 & 33.47 \\
\hline
\end{tabular}

* Abbassid glazes are divided into two categories: "Abbassid 1" have a homogeneous composition; "Abbassid 2" are very scattered and minimum and maximum measured values are indicated. 


\section{IX'th-X $\mathbf{X}^{\text {th }}$ centuries}

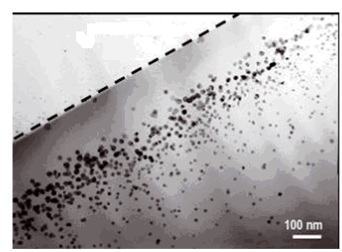

gold lustre

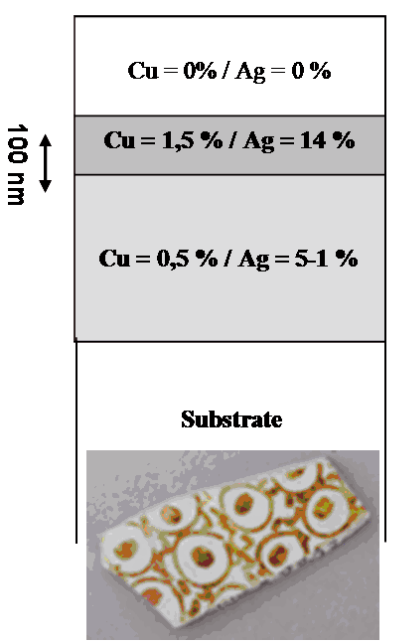

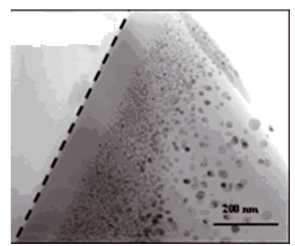

red lustre

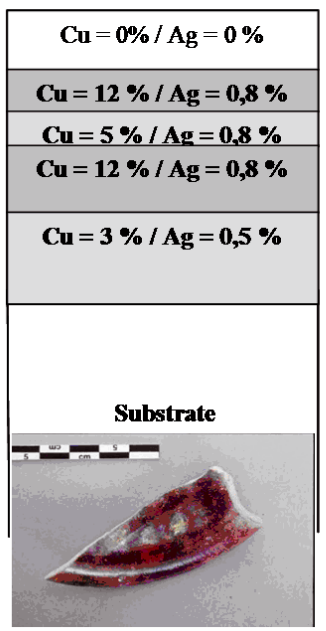

XVIIIth century

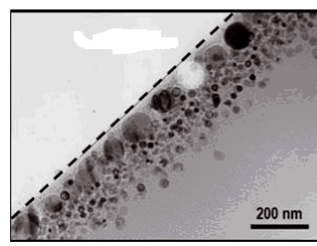

“ copper" lustre

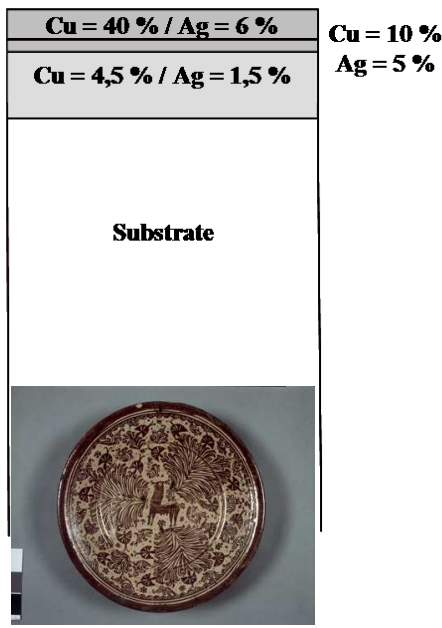

Fig. 7. Three lustre structures observed in TEM and corresponding results by RBS analysis simulation. TEM micrographs kindly provided by P. Sciau, CEMES-CNRS, Toulouse. Concentrations are in at. $\%$.

Fig. 7. Trois microstructures de lustres observées en MET et résultats des simulations RBS correspondantes. Micrographies MET aimablement fournies par P. Sciau, CEMES-CNRS, Toulouse. Concentrations en \%at.

layer, more useful for interpreting and modelling the optical properties $[8,9]$. This fraction was calculated by considering that both elements are in metallic form. It is known from the literature [24] that this assumption is not entirely satisfied for copper, which can be present as both the metallic and oxide states in the lustre; this means that the copper volume fractions may be overestimated here. Unfortunately, the precision of X-ray diffraction and also diffraction peak interference problems made it impossible to check that point in the present work. In fact, it is the reason why the work cited [24] was done with another technique, based on synchrotron X-ray absorption spectrometry.

Instead of giving a full and unreadable table of all the data, the following figures (Figs. 8 to 11) tend to summarise the most characteristic features which may provide evidence of the evolutions in the manufacturing techniques. A detailed analysis of all the results led to choosing the following criteria found to be useful to attempt a comparison amongst the productions:

- The "surface layer thickness" describes the presence or absence of an extreme surface layer containing neither copper nor silver and its thickness when it exists; this parameter is important to compare the present results with observations usually reported in the literature (see, for instance $[4,5,7,14]$ ).

- The "total thickness" is the sum of thicknesses of all the surface layers containing silver and copper (or an excess of copper if copper is present in the lustre-free glaze) plus the thickness of the extreme surface metal-free layer when it exists; such a parameter may provide information on the temperature and time of the final firing.

- The "total copper amount" and "total silver amount" sum up the quantity 


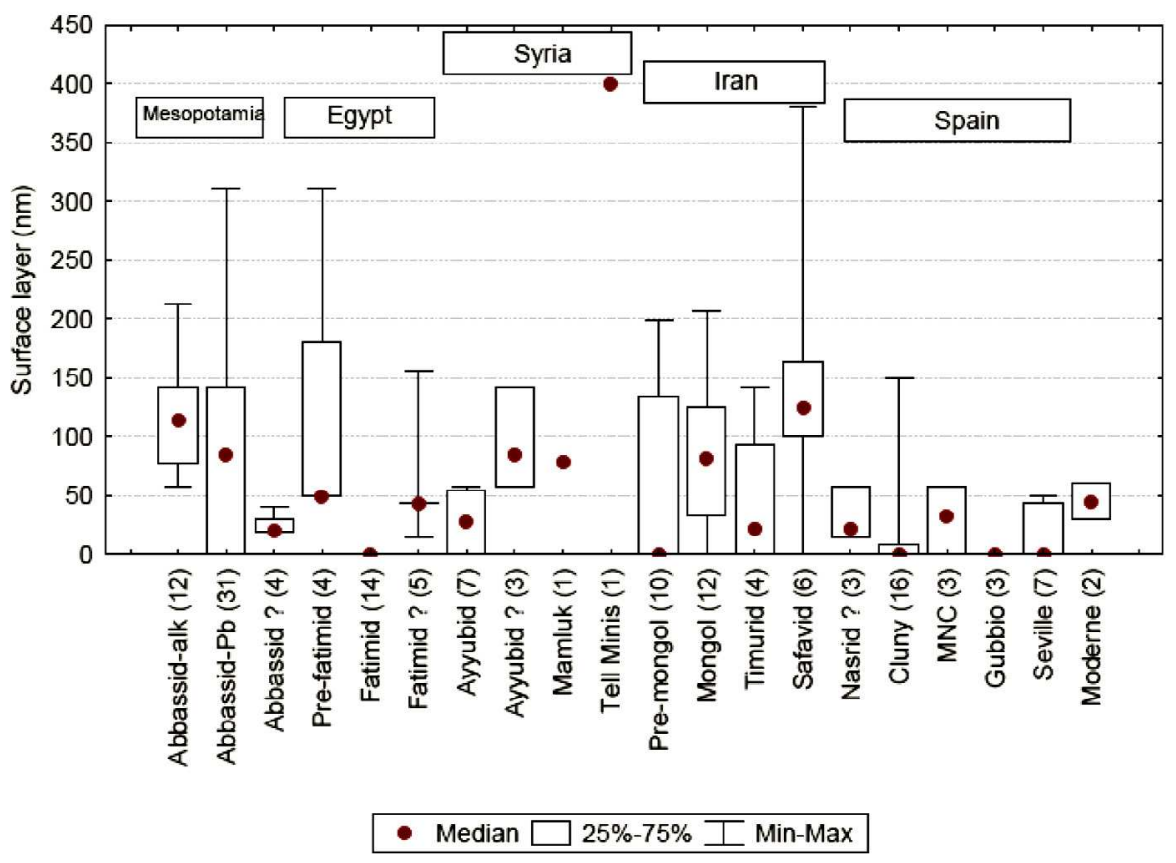

Fig. 8. Statistical comparison of the productions from the viewpoint of the presence and thickness (in $\mathrm{nm}$ ) of an extreme surface particle-free layer. See text for definition of the production groups. Fig. 8. Comparaison statistique des productions du point de vue de la présence et de l'épaisseur (en nm) d'une couche d'extrême surface exempte de particules. Voir le texte pour la définition des groupes de production.

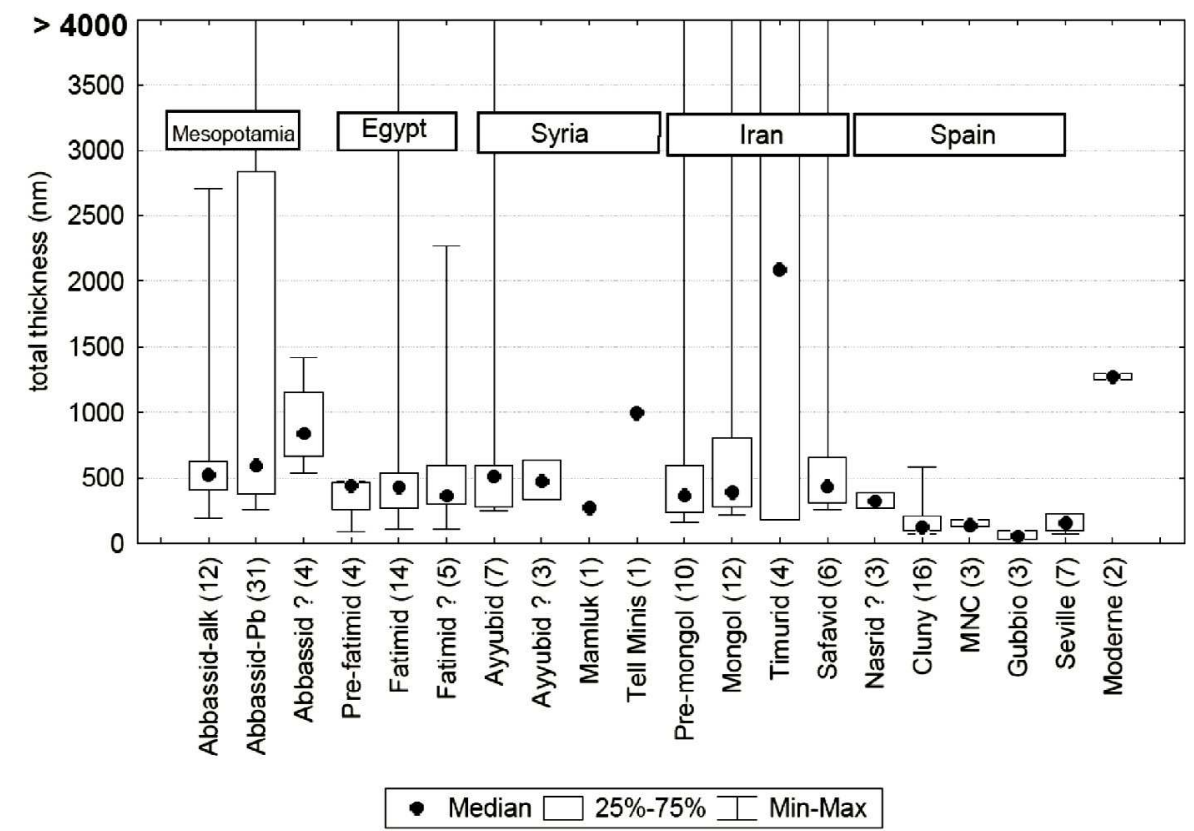

Fig. 9. Statistical comparison of the productions from the viewpoint of the total thickness of the lustre, i.e. the sum of all layers containing $\mathrm{Ag}$ and/or $\mathrm{Cu}$ particles, plus the extreme surface metal-free layer when it exists. See text for definition of the production groups.

Fig. 9. Comparaison statistique des productions du point de vue de l'épaisseur totale du lustre, soit la somme de toutes les couches contenant des nanoparticules de Ag et/ou Cu, plus la couche d'extrême surface sans métal si elle existe. Voir le texte pour la définition des groupes de production. 

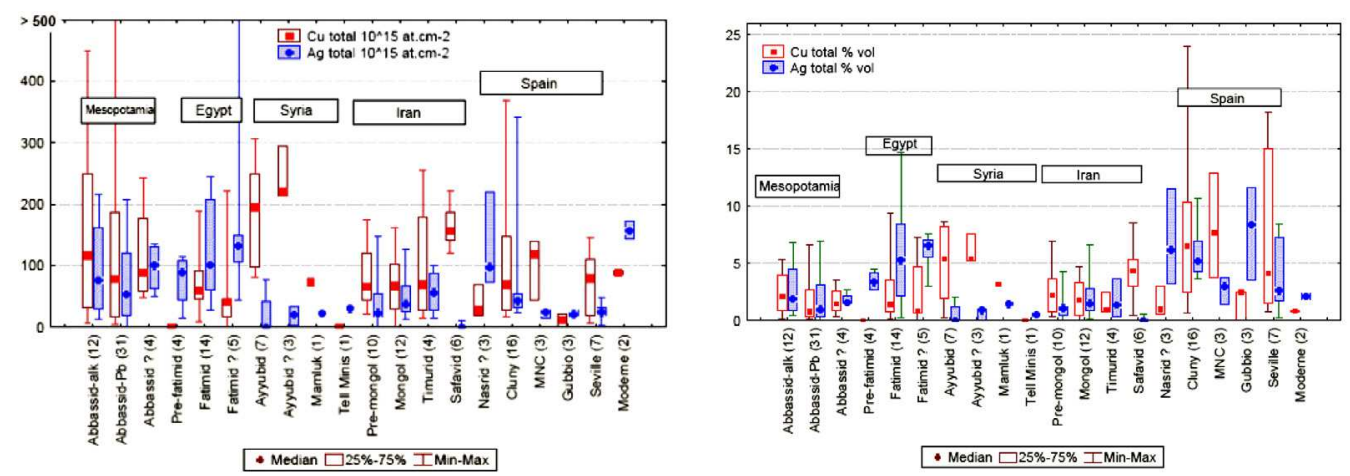

Fig. 10. Comparison of the productions from the viewpoint of the total $\mathrm{Cu}$ and/or Ag content of the lustre layers (left) and of the $\mathrm{Cu}$ and/or Ag volume fraction contained in the lustre layers. See text for definition of the production groups and of the volume contents.

Fig. 10. Comparaison statistique des productions du point de vue de la quantité totale de Cu et/ou Ag (gauche) et de la fraction volumique de Cu et/ou Ag dans les couches de lustres. Voir le texte pour la définition des groupes de production et des fractions volumiques.
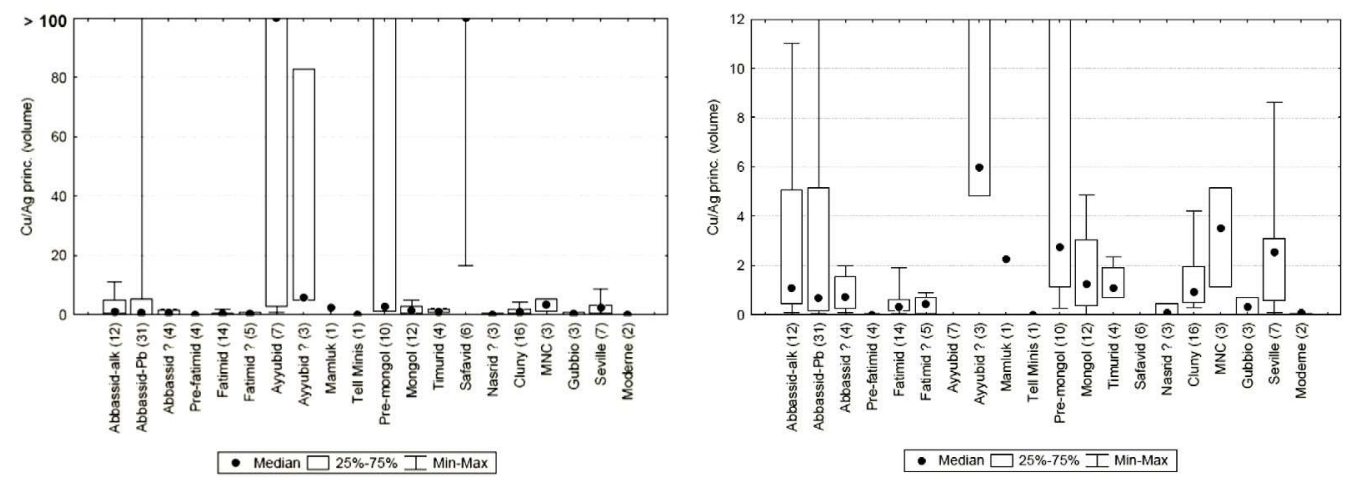

Fig. 11. Left: comparison of the productions from the viewpoint of the $\mathrm{Cu} / \mathrm{Ag}$ volume fraction ratio in the main lustre layer (layer with the maximum $\mathrm{Cu}$ or $\mathrm{Ag}$ content) $>100$ values are in fact generally infinite (Ag content is zero). Right: a close-up of the low values of the left diagram. See text for definition of the production groups and of the volume contents.

Fig. 11. Gauche: comparaison des productions du point de vue du rapport des fractions volumiques Cu/Ag dans la couche de lustre principale (couche avec la concentration maximale en $\mathrm{Cu}$ ou $\mathrm{Ag}$ ). $>100=$ valeurs en général infinies (concentration nulle en $\mathrm{Ag}$ ). Droite : agrandissement des valeurs basses du diagramme de gauche. Voir le texte pour la définition des groupes de production.

(expressed in at.cm ${ }^{-2}$ ) of each of these two metallic elements contained in the lustre layers; this may be representative of the composition of the mixture applied by the potter to obtain the lustre.

- The "total copper volume fraction" and "total silver volume fraction" (in \%) express the average volume fractions of copper and silver over the total thickness of the lustre; these values are the result of a combination of the two preceding parameters.

- The "main layer copper over silver volume fraction ratio" is the ratio between the copper and silver volume fractions in the "main layer"; this parameter may give a representation of the potter's intention to give a specific colouration to the lustre.

It is clear that, being the result of artisan handwork, the productions are not uniform and give rise to a significant dispersion of the criteria within one given group. Nevertheless, some trends can be detected through a statistical study. Figures $8-11$ show a statistical evaluation of the preceding five criteria, comparing among the different productions. The quantitative values used for the statistical computation are gathered in the extra Figures A1-A5 given in Appendix 2. For each production group and each criterion, 
Figures 8-11 give "box-and-whisker" plots, showing for each group the median value (the value for which the numbers of objects with higher and lower values are equal), a box which delimits the values adopted by $25 \%$ to $75 \%$ of the population, and the two maximum and minimum values (whiskers) observed in the population. The number of objects (or different decorations when more than one colour is present on the same object) considered for each production is indicated on the abscissa axis in each figure.

The groups are defined in a chronogeographical manner, following the groups described in Table 1. The Abbasid group is divided into 2 subgroups, depending on the nature of the glaze; "Abbasid-alk" concerns the fragments with an alkaline glaze and "Abbasid- $\mathrm{Pb}$ " the fragments with a lead glaze. The group "Abbasid?" concerns the four specimens found in Fustat but with an uncertain attribution (third line of Tab. 1) [15]. The groups "Fatimid ?", "Ayyubid?" and "Nasrid?" are for the specimens with an uncertain origin (also reported in Tab. 1). The Hispano-Moresque production is divided into four sub-groups: "Cluny" for the plates of the Cluny Musée du MoyenAge, "MNC" for the fragments of the Musée National de la Céramique, "Gubbio" for the fragments found in Gubbio (Italy) but clearly belonging to a Spanish HispanoMoresque fabrication [25] and "Seville" for the fragments found in Seville and described in [11]. The Algerian group (La Qala de Banu Hammad) of Table 1 is not included in the analysis because the experimental results are not of sufficient reliability.

If one focuses on these criteria, the following trends may be seen:

- The most ancient productions, namely corresponding to the Mesopotamian Abbasid sites and to the fragments found in Fustat (probably to be attributed to intermediate productions) exhibit a quite thick metal-free surface layer. This is no longer true for the later productions (Fatimid), for which that surface layer is absent; it appears again in the Syrian and Iranian productions; in Spain, it becomes much thinner and even disappears for a large proportion of the Hispano-Moresque specimens; however, the metal-free surface layer is always present on Italian majolica [4].

- For the Mesopotamian or Mesopotamian-like productions, the sum of the principal layer and gradient layers extends over a thickness reaching several micrometres, and this is also true for the modern artisan's recreation (whose recipe was probably copied from the most ancient tradition). That sum is much smaller for the other productions, where the thickness concerned rarely exceeds $500 \mathrm{~nm}$ (except for Timurid shards) and is more often of the order of a few hundreds of nanometres; it falls under $200 \mathrm{~nm}$ for the Spanish Hispano-Moresque objects [26]. For Italian majolica that total thickness is even smaller [4].

- As for the copper and silver contents present (as metallic nanoparticles) in the lustre layers, they evidently depend on the final aspect. The individual copper and silver contents in the lustre layers never exceed 14 at. \%, except for the late (18th century) Hispano-Moresque objects where they may reach 40 at.\%. From a general viewpoint, it may be said that those contents tend to increase with time, as the layers become thinner. A comparison of the two diagrams of Figure 10 is interesting: the total amount of silver and/or copper is of the same order in nearly all the productions but, owing to the differences in thickness, the final volume fraction of both metals is the lowest for the Mesopotamian lustres and the highest for the Hispano-Moresque lustres. Concerning the latest HispanoMoresque productions it is worth noting that, despite their very marked copperred aspect, the lustre layers still contain noticeable quantities of silver, in opposition to a commonly expressed idea [1] which suggests that the potters of that period ceased to add silver to the paste mixture used for lustre elaboration.

- When one considers the $\mathrm{Cu} / \mathrm{Ag}$ ratios, the diagrams of Figure 11 show that the Ag content is very small for a few of the productions (Ayyubid, pre-Mongol and Safavid): it is even zero for all the Safavid production, known to constitute 
copper-like coloured lustres on alkaline glaze. The close-up shown in the right part of Figure 11 gives an idea of the distribution of the $\mathrm{Cu} / \mathrm{Ag}$ ratio around the value of unity, sometimes considered as a criterion to separate red-like lustres from golden-like lustres. It is now admitted $[14,15]$ that the lustre colour is not entirely governed by the $\mathrm{Cu} / \mathrm{Ag}$ ratio.

- A last point is worth underlining: the latest Spanish productions (18th century) are lustres with a strong copper-like shine, and the surface layers indeed contain high amounts of copper (20 to $25 \%$ in volume fraction), although the surface layers still contain noticeable contents of silver [26]. The Iran Safavid lustres, produced in the same period, show a comparable copper-like aspect and the surface layers also contain high amounts of copper but generally no silver. Both decorations are applied over transparent (tin-free) glazes (Tab. 3), and the question might be raised of a possible influence of the late Spanish potters' knowhow on the renewal of lustre fabrication in Iran during the 17th and the 18th centuries [27].

\section{Conclusions}

A study of metallic lustre decoration cannot be achieved without a comprehensive knowledge of its background; that is, of the glazes, and indirectly of the base terracotta.

First of all, if one focuses on the Abbasid production, which can be considered as the reference because it is the first known metallic lustre on glaze, it constitutes a homogeneous entirety of terracotta. These are covered with glazes which can be either purely alkaline or alkaline with small lead amounts $(\mathrm{PbO} \leq 6 \mathrm{wt} \%)$. The latter seem to correspond to a transition period of progressive introduction of lead and tin. For later periods, different ceramic technologies are used for the different studied productions. No correlation was observed between the kind of ceramic body (baked clay or siliceous) and the glaze type (alkaline or lead-bearing alkaline). Yet, inside the same production site, a certain coherency can be shown in the results, specific to the production. Fatimid ob- jects, in baked clay or siliceous paste, are systematically covered with lead-bearing alkaline glazes. The Ayyubid period shows a constant use of alkaline glazes affixed on siliceous paste. Hispano-Moresque objects are systematically elaborated from roasted clay and covered with lead glazes opacified with tin, to the noticeable exception of the end of the production (18th century), where the use of tin disappears.

About the metallic lustre, the following conclusions may be drawn:

For the Abbasid production, our reference, the use of copper and silver in various proportions leads to obtaining different colours or tones for the decoration. In other words, the lustring mixture is a function of the desired result (speaking only of the $\mathrm{Cu}$ and $\mathrm{Ag}$ proportions, independently of the unknown possible influence of other compounds of the mixture). Yet, we suppose that the cooking process (temperature, reducing atmosphere) is relatively similar and mastered: systematic occurrence of a surface layer without copper and silver, similar thicknesses of the main layers, and quasisystematic occurrence of in-depth gradient. Each studied further production has its own technological specificity, shown here by the different layers and gradients of the decoration, which differentiates it from the Abbasid production: disappearance of the surface metal-free layer, variations in the metallic lustre layer thickness, variations in the copper and silver contents, etc. It seems thus that the metallic lustre technique has been adapted to a known local ceramic production, or, more precisely, to the nature of the glaze used locally (alkaline or lead-bearing). It should be mentioned additionally that the latter also plays an important role in the firing process (melting or softening temperature of the glaze) and that it has an evident influence on the decoration microstructure.

We thus observe a constant back-andforth between the aesthetic desire and the technological choice, illustrated by the choice of copper and silver proportions. Variable proportions of $\mathrm{Cu}$ and $\mathrm{Ag}$, already applied under the Abbasids, are again found under the Fatimids in the Orient and at the beginning of the Hispano-Moresque period in the Occident. The consequence is a 
chromatic variety of the decoration. For instance, the Fatimid lustre on coloured glazes uses a major proportion of silver, thus allowing a good readability of the decoration.

On the contrary, a certain standardisation of the technology seems to be put in place for the Ayyubid period and also for the end of the Hispano-Moresque production, and this leads to some loss of the variety in the decoration colours. It is probably not a consequence of a loss of technology (the metal quantities in the lustre are still as significant or even larger) but rather an aesthetic desire. As an example, one may consider the decorations produced at the end of the Hispano-Moresque period, which show a strong coppered aspect: the use of tin in the glaze is suddenly avoided. Without forgetting an always possible economic reason, one may consider an aesthetic choice. The probably fashionable coppered aspect sought in that period agrees better with a cream-like background (colour of the body across the transparent glaze) than with a bright white background (colour of an opacified glaze).

\section{Acknowledgements}

This article is dedicated to the memory of Joseph Salomon, head of the AGLAE accelerator for the past 20 years. This study would not have existed without his active contribution. Alex Kaczmarczyk $^{\dagger}$ lent some of his fragments; Miguel Ruiz Jimenez gave spare modern fragments produced by himself [12]. This study was possible thanks to a post-doctorate fellowship supplied by CNRS to D. Chabanne. We are also indebted to the AGLAE team and the photographers of C2RMF for their technical support, and to Philippe Sciau (CEMES CNRS), who kindly supplied TEM photographs.

\section{References}

[1] A. Caiger-Smith, Lustre Pottery: Technique, Tradition and Innovation in Islam and the Western World, Faber and Faber, London, UK, 1985

[2] R.B. Mason, Shine like the sun: LustrePainted and Associated Pottery from the Medieval Middle East, Mazda Press, Costa Mesa, California and the Royal Ontario Museum, Toronto 2004, http://www. rbmason.ca/Shine/index.html
[3] W.D. Kingery, P. Vandiver, An Islamic Lusterware from Kashan, Ceramic masterpieces: Arts, Structure and Technology, Free Press, New-York, 1986, pp. 111-121

[4] G. Padeletti, G.M. Ingo, A. Bouquillon, S. Pages-Camagna, M. Aucouturier, S. Roehrs, P. Fermo, Appl. Phys. A 83 (2006) 475-483

[5] D. Chabanne, Le décor de lustre métallique des céramiques glaçurées (IXe-XVII ${ }^{\mathrm{e}}$ siècles) : matériaux, couleurs et techniques. Principales étapes de diffusion d'une invention mésopotamienne, Ph.D. Thesis, Bordeaux 3 University, 2005

[6] C.C. Piccolpasso, The three books of the potter's art, Victoria and Albert museum, 1558

[7] J. Perez-Arantegui, J. Molera, J. Larrea, A. Pradell, T. Vendrell-Saz, I. Borgia, B.G. Brunetti, F Cariati, P. Fermo, M. Mellini, A. Sgamelotti, C. Viti, J. Am. Ceram. Soc. 84 (2001) 442-446

[8] S. Berthier, G. Padeletti, P. Fermo, A. Bouquillon, M. Aucouturier, E. Charron, V. Reillon, Appl. Phys. A 83 (2006) 573-579

[9] V. Reillon, S. Berthier, C. Andraud, Physica B 394 (2007) 242-247; V. Reillon, S. Berthier, C. Andraud, Appl. Phys. A 100 (2010) 901-910

[10] O. Bobin, M. Schvoerer, J.L. Miane, J.F. Fabre, J. Non-Cryst. Solids 332 (2003) 28-34

[11] A. Polvorinos del Rio, J. Castaing, M. Aucouturier, Nucl. Instrum. Methods Phys. Res. B 249 (2006) 596-600

[12] http://www.miguelruizjimenez.com/

[13] M. Aucouturier, E. Darque-Ceretti, Chem. Soc. Rev. 36 (2007) 1605-1621

[14] D. Hélary, E. Darque-Ceretti, M. Aucouturier, J. Am. Ceram. Soc. 88 (2005) 3218-3221

[15] E. Darque-Ceretti, D. Hélary, A. Bouquillon, M. Aucouturier, Surf. Eng. 21 (2005) 352-358

[16] A. Guinier, Théorie et technique de la radiocristallographie, Dunod, Paris, 1964

[17] T. Calligaro, J.-C. Dran, J. Salomon, Ion beam microanalysis, in Non-destructive microanalysis of cultural heritage materials, edited by K. Janssens, R. Van Grieken, Comprehensive Analytical Chemistry XLII, Elsevier, Amsterdam, 2005, pp. 227-276

[18] J.A. Maxwell, J.L. Campbell, W.J. Teesdale, Nucl. Instrum. Methods Phys. Res. B 43 (1988) 218-230

[19] M. Mayer, SIMNRA, (C) Max-Planck-Institut für Metallphysik, 1997-1998, http://www. rzg.mpg.de/

[20] D. Chabanne, O. Bobin, M. Schvoerer, C. Ney, Metallic lustre of glazed ceramics: evolution of decorations in search for discriminating elements, 34th internat, Symposium on Archaeometry, Zaragoza May, 2004, pub. on-line: http://www.dpz.es/ifc/libros/libros. htm 
[21] S. Lahlil, A. Bouquillon, G. Morin, L. Galoizy, C. Lorre, Archaeometry 51 (2009) 774-790

[22] D. Arnold, Studien zur altägyptischen Keramik, Verlag Philipp von Staben (SDAIK 9), Mainz am Rhein, 1981

[23] F. Hamer, J. Hamer, The potter's dictionary of materials and techniques, A et C Black, London, 1997, p. 406

[24] S. Padovani, D. Puzzovio, C. Sada, P. Mazzoldi, I. Borgia, A. Sgamellotti, B.G. Brunetti, L. Cartechini, F. D'acapito, C. Maurizio, F. Shokoui, P. Oliaiy, J. Rahighi, M. Lamehi-rachti, E. Pantos, Appl. Phys. A 83 (2006) 521-528
[25] D. Chabanne, A. Bouquillon, M. Aucouturier, X. Dectot, G. Padeletti, Appl. Phys. A 92 (2008) 11-18

[26] X. Dectot, Les céramiques hispaniques $\left(\mathrm{XII}^{\mathrm{e}}-\mathrm{XVIII}{ }^{\mathrm{e}}\right.$ siècle), Musée national du Moyen-Âge, Thermes et Hôtel de Cluny, Paris, Réunion des Musées nationaux, 2007, p. 160

[27] S. Makariou, Et retour vers l'Orient ? in Reflets d'or. D'Orient en Occident la céramique lustrée, exhibition catalogue, edited by X. Dectot, S. Makariou, D. Miroudot exhibition curators, Paris, Réunion des Musées nationaux, April 2008, p. 107

See Appendices next pages 


\section{Appendix 1: The studied ceramics (C) C2RMF, D. Bagault)}

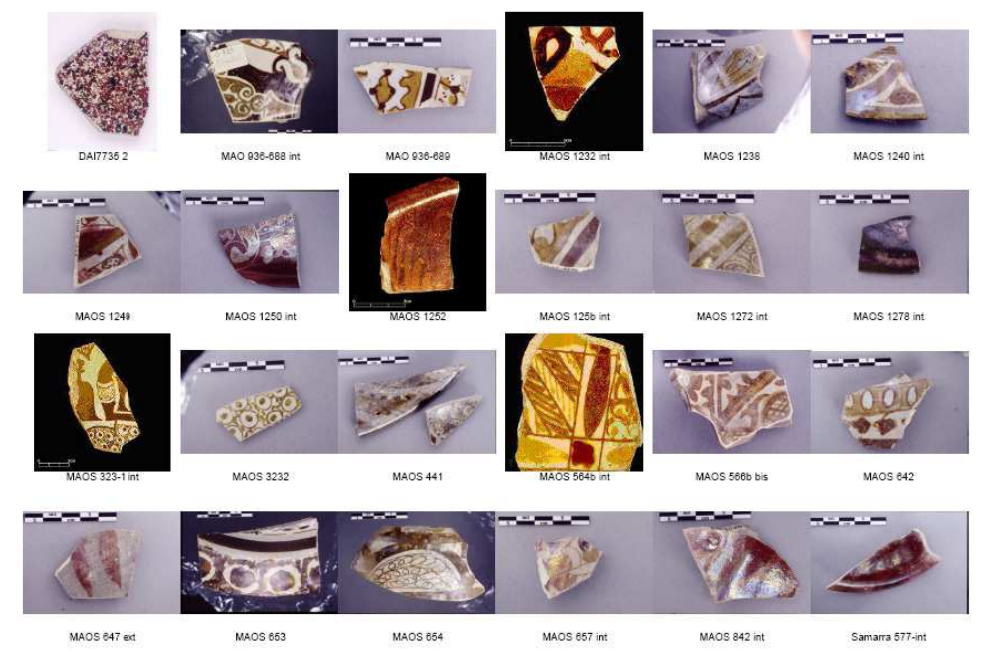

Abbasids

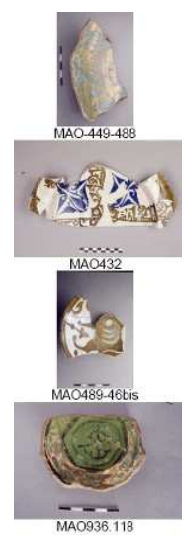

EGYPT,

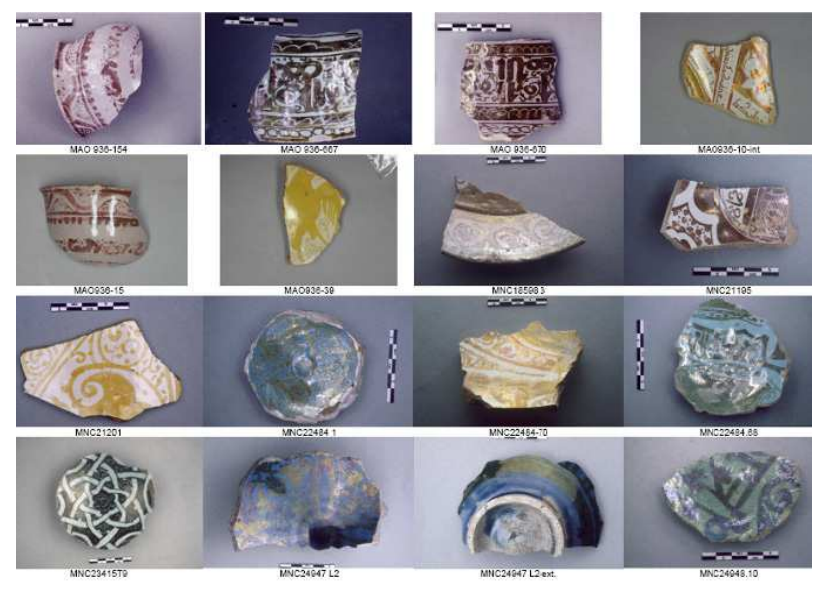

EGYPT, Fatimids

pre-fatimids

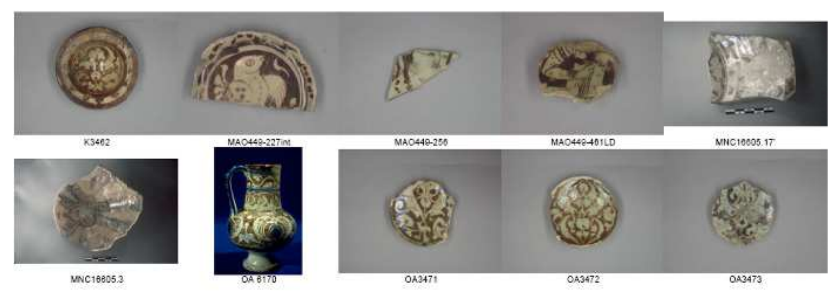

SYRIA, Ayyubids

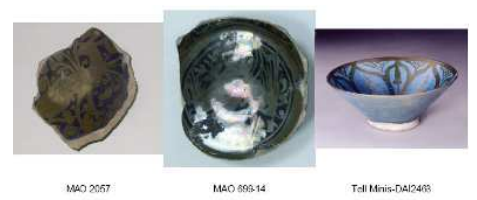

SYRIA, Mamluk and Tel Minis 


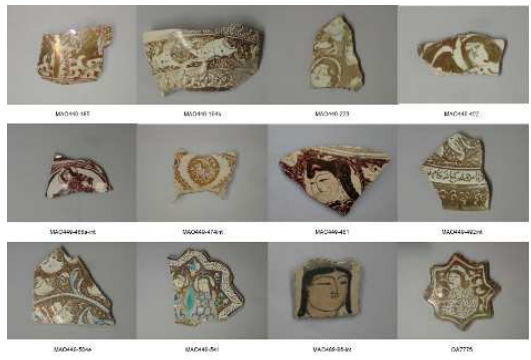

IRAN, pre-mongols

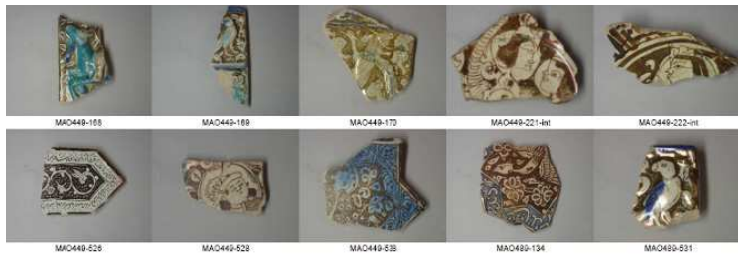

IRAN, Mongols
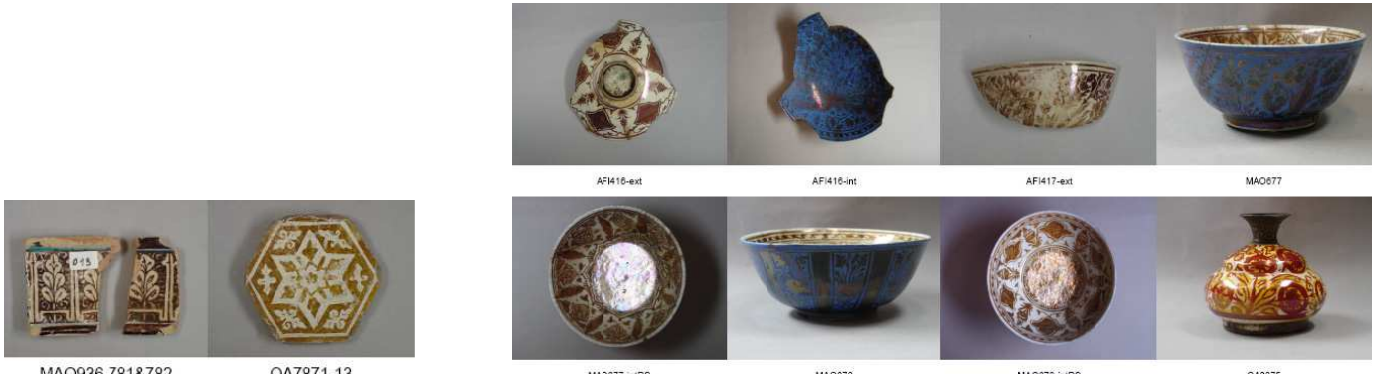

RAN, Timurids

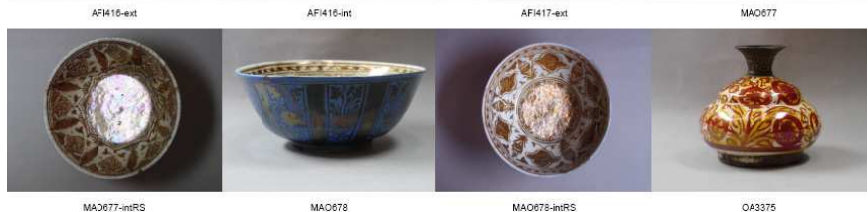

IRAN, Safavids
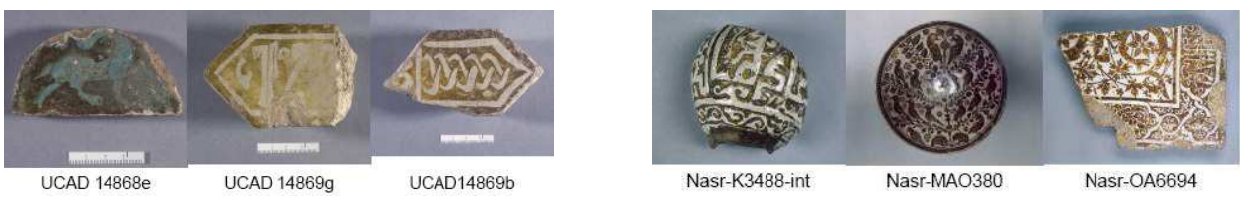

ALGERIA

ISLAMIC SPAIN, $12^{\text {th }}-14^{\text {th }}$ cent.
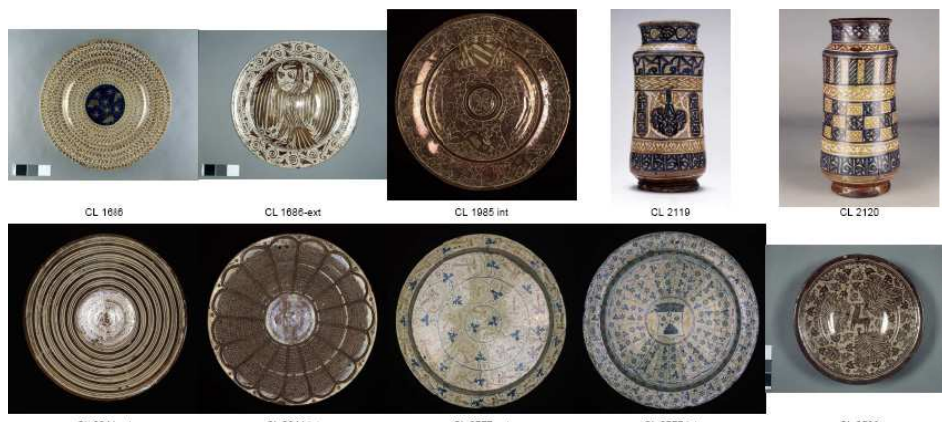

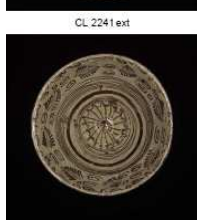

CL. 8617 ext

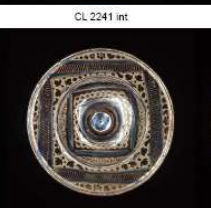

CL.8617 int
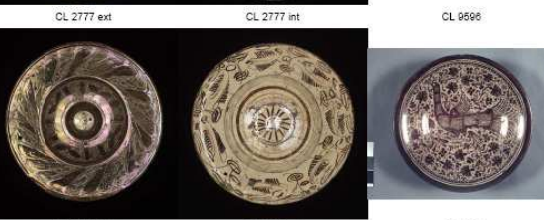

CL 2023

SPAIN, Valencia region, Cluny museum

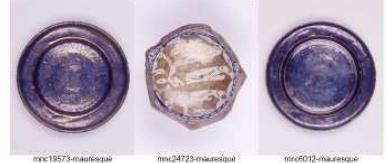

SPAIN, Valencia region

Musée National de la Céramique 


\section{Appendix 2: Quantitative individual values used for the statistical Figures 8 to 11}

See text for definition of the production groups.

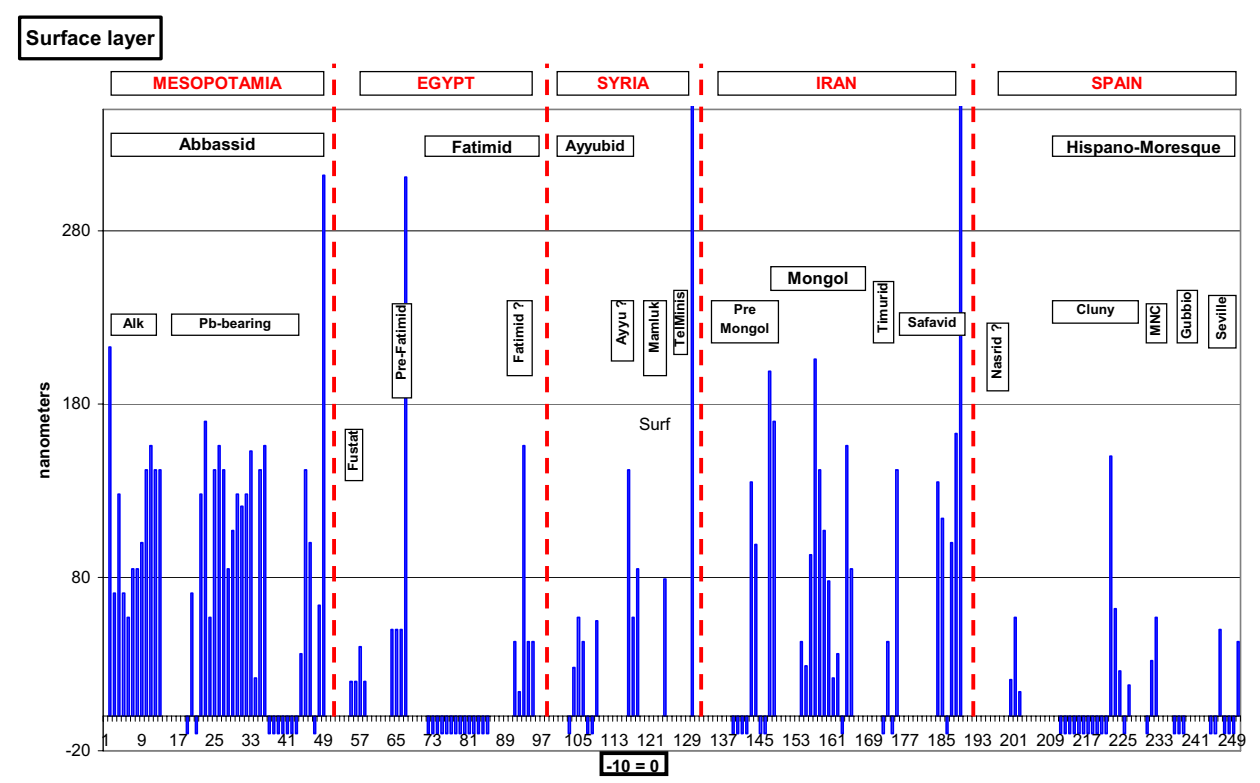

Fig. A1. Thickness of the silver and copper-free surface layer for each lustre. "-10" means the absence of surface layer.

Fig. A1. Épaisseur de la couche d'extrême surface sans Ag ni Cu, pour tous les objets. "-10 » signifie l'absence de couche de surface.

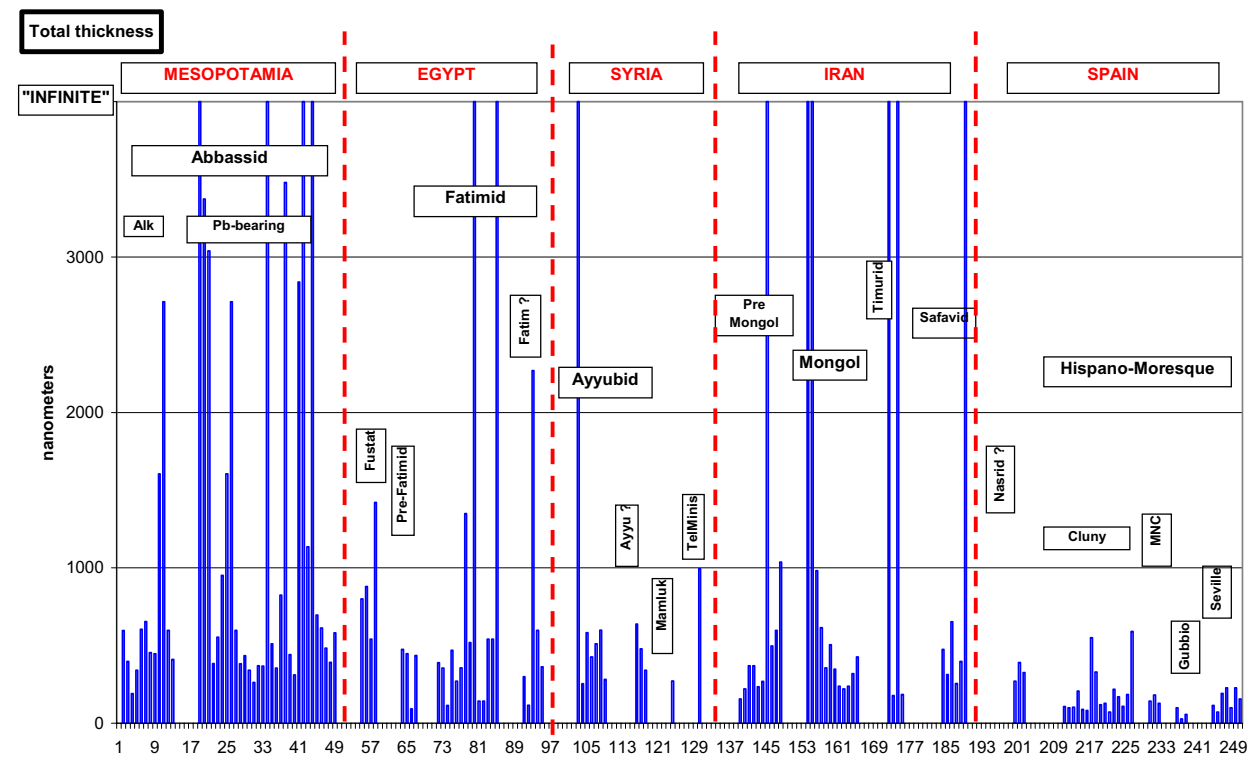

Fig. A2. Total thickness of each lustre (sum of the surface metal-free layer and of the layers containing metallic copper and silver nanoparticles). "Infinite" means a thickness larger than the thickness explored by RBS (>5 $\mu \mathrm{m})$.

Fig. A2. Épaisseur totale pour tous les lustres (somme de la couche d'extrême surface sans métal et des couches contenant des nanoparticules de $\mathrm{Cu}$ ou $\mathrm{Ag}$ ). "Infinite» signifie une épaisseur plus grande que l'épaisseur explorée par RBS (>5 $\mu \mathrm{m}$ ). 


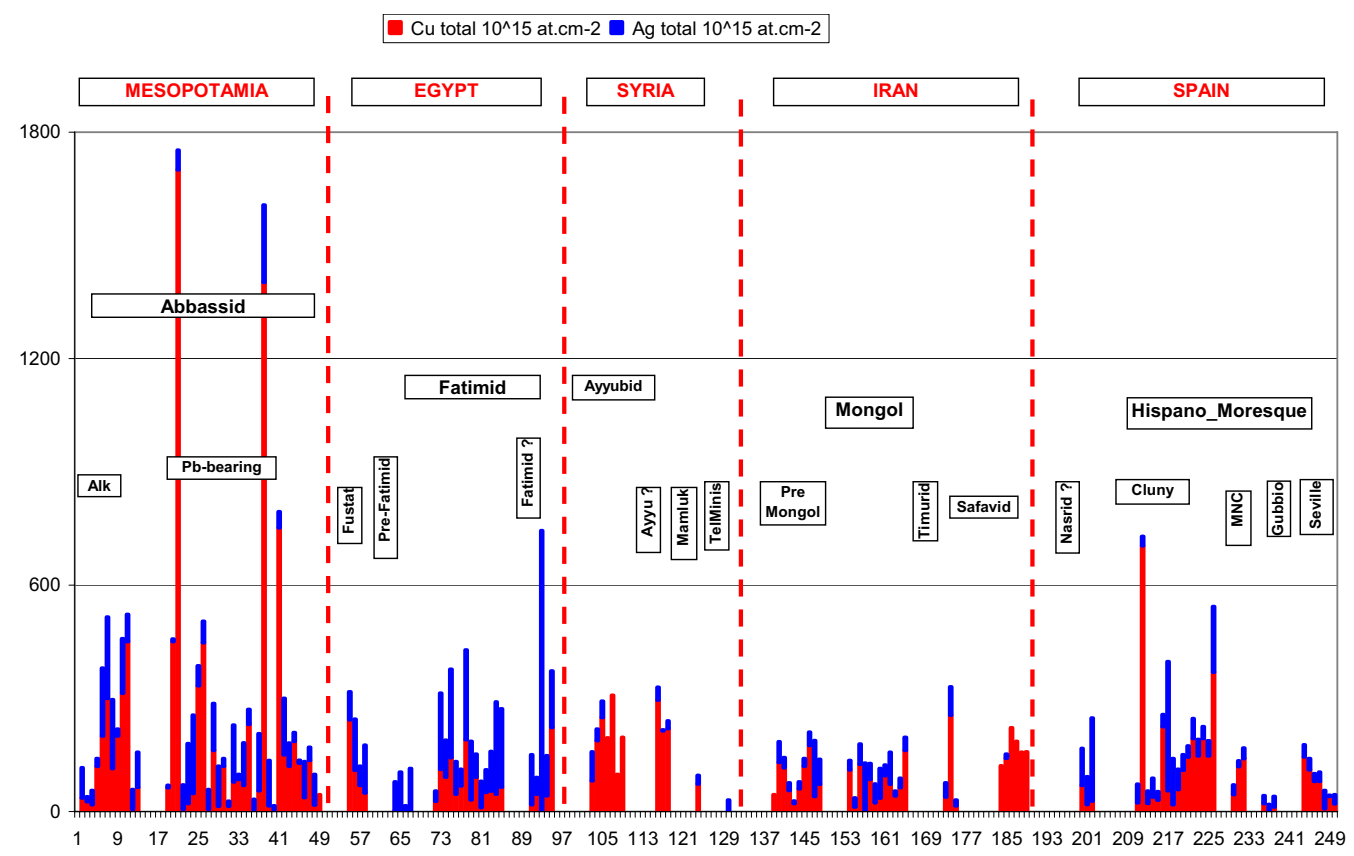

Fig. A3. Total copper and silver contents in each lustre, expressed in at.cm ${ }^{-2}$.

Fig. A3. Contenu total en cuivre et argent pour tous les lustres, en at. $\mathrm{cm}^{-2}$.

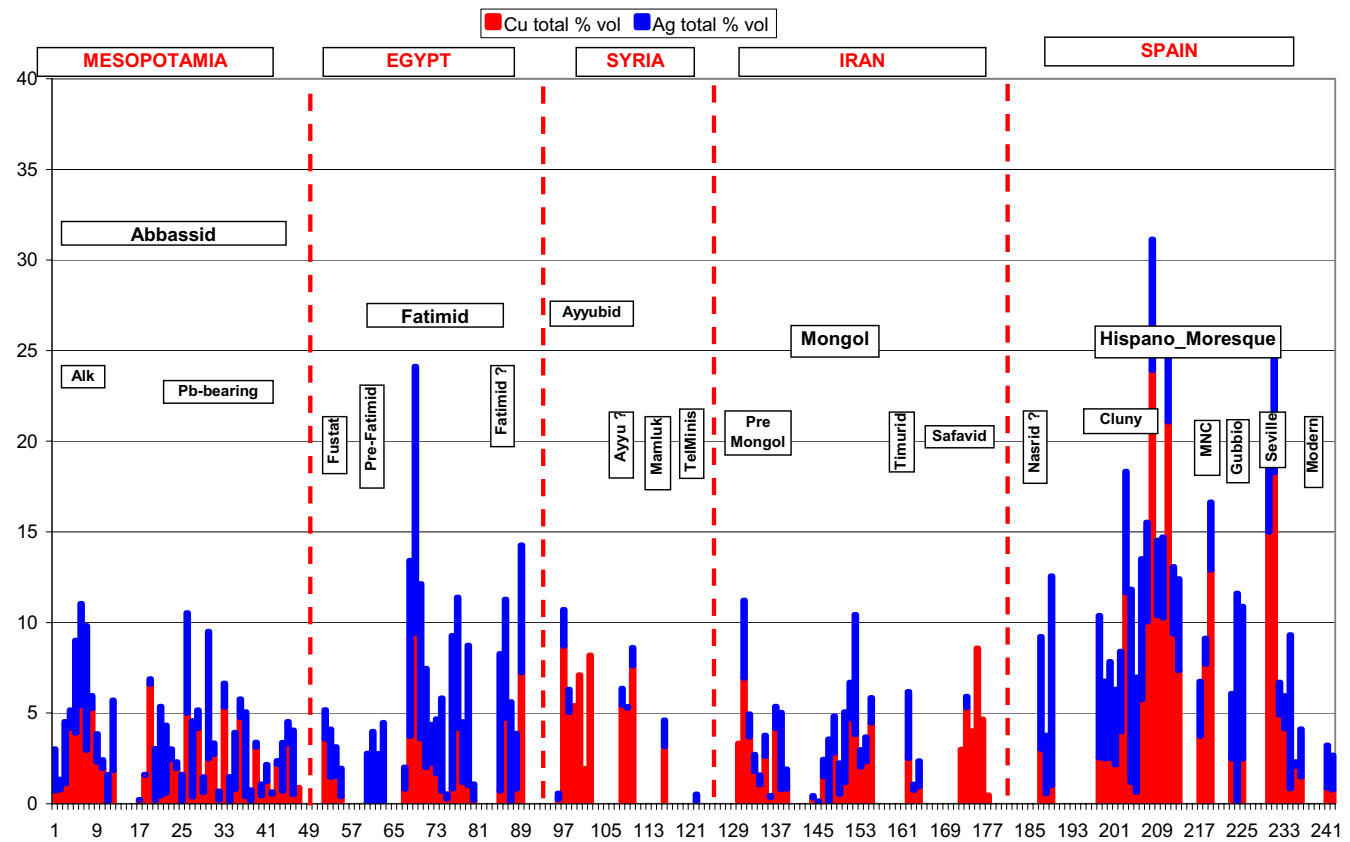

Fig. A4. Copper and silver volume fraction (in \%) in each lustre layer (see text for definition of the volume fraction).

Fig. A4. Fractions volumiques (en \%) de Cu et Ag pour tous les lustres (voir texte pour la définition des fractions volumiques). 


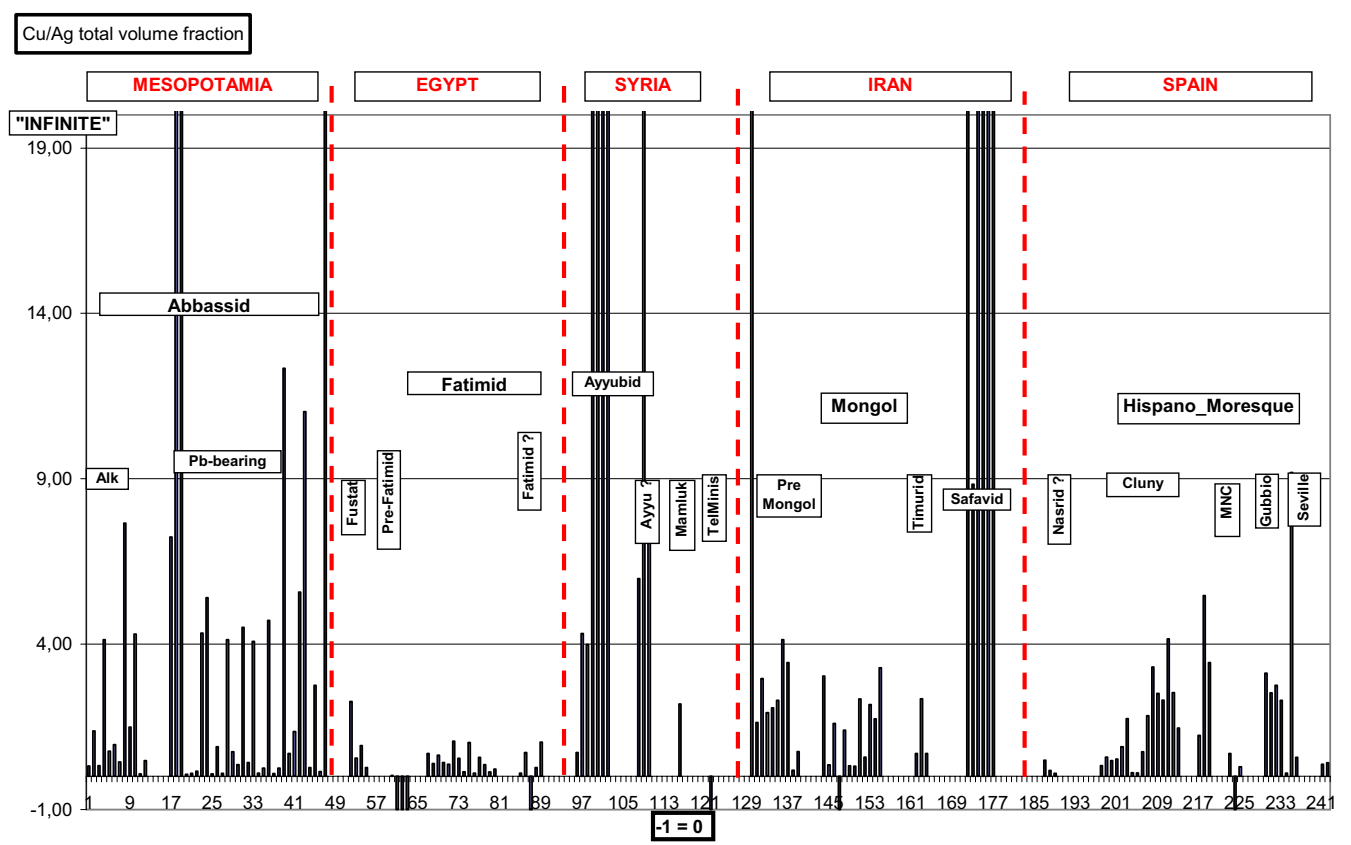

Fig. A5. $\mathrm{Cu} / \mathrm{Ag}$ volume fraction ratio for each lustre. "-1" means $\mathrm{Cu} / \mathrm{Ag}=0$ (no copper); "Infinite" means no silver.

Fig. A5. Rapport des fractions volumiques Cu/Ag pour tous les lustres. «-1» signifie $C u / A g=0$ (pas de cuivre); «infinite » signifie pas d'argent. 